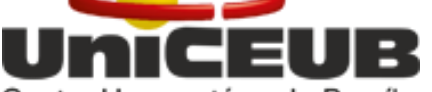 \\ Centro Universitárı de Brasílıa \\ CENTRO UNIVERSITÁRIO DE BRASÍLIA - UniCEUB \\ PROGRAMA DE INICIAÇÃO CIENTÍFICA
}

PEDRO NUNES SILVA

AVALIAÇÃO FUNCIONAL PROSPECTIVA DA RECONSTRUÇÃO DO LIGAMENTO CRUZADO ANTERIOR: AUTOENXERTO PATELAR IPSILATERAL

VERSUS CONTRALATERAL

BRASÍLIA

2019 


\section{Uกीट्uB \\ Centro Unıversitárıo de Brasílıa}

PEDRO NUNES SILVA

AVALIAÇÃO FUNCIONAL PROSPECTIVA DA RECONSTRUÇÃO DO LIGAMENTO CRUZADO ANTERIOR: AUTOENXERTO PATELAR IPSILATERAL

VERSUS CONTRALATERAL

Relatório final de pesquisa de Iniciação

Científica apresentado à Assessoria de Pós-

Graduação e Pesquisa.

Orientação: Marcio de Paula e Oliveira

BRASÍLIA 


\title{
AVALIAÇÃO FUNCIONAL PROSPECTIVA DA RECOSNTRUÇÃO DO LIGAMENTO CRUZADO ANTERIOR: AUTOENXERTO PATELAR IPSILATERAL VERSUS CONTRALATERAL
}

\author{
Pedro Nunes Silva - UniCEUB, PIC HOME, aluno bolsista \\ pedro.nunes@sempreceub.com
}

\author{
Marcio Oliveira - UniCEUB, professor orientador \\ marcio.oliveira@ceub.edu.br
}

A ruptura do ligamento cruzado anterior (LCA) tem sido objeto de estudo desde o século IX, sendo uma das mais frequentes e debilitantes lesões do joelho, especialmente no âmbito esportivo. $O$ tratamento cirúrgico é indicado na maior parte dos casos e, apesar de ser um dos procedimentos ortopédicos mais realizados no mundo, a escolha do enxerto ainda envolve grande controvérsia na literatura, sendo influenciada por fatores como a experiência do cirurgião, condições da região doadora e expectativas funcionais do paciente. O objetivo do presente trabalho foi avaliar e comparar de forma prospectiva, do ponto de vista clínico e funcional, pacientes submetidos a reconstrução do ligamento cruzado anterior, utilizando o autoenxerto do ligamento patelar ipsilateral ou contralateral. Foi realizado um estudo longitudinal descritivo com 54 pacientes de ambos os gêneros, dos quais 27 foram operados com enxerto patelar ipsilateral ( 25 homens e 2 mulheres) e 27 com enxerto patelar contralateral ( 23 homens e 4 mulheres). Para avaliação dos pacientes foram aplicadas a Escala Visual e Analógica de Dor, a Escala de Atividades de Vida Diária e o Questionário e Lysholm. Foram realizadas também as avaliações da amplitude de movimento, estabilidade articular objetiva (KT-1000 ${ }^{\mathrm{TM}}$ ), desempenho muscular (dinamometria isocinética) e capacidade sensório-motora (Single Leg Hop Test e Y Balace Test). Todas as avaliações foram realizadas no período pré-operatório e ao final do 3ㅇ mês pós cirúrgico. Os pacientes que operaram utilizando o autoenxerto patelar contralateral sofreram mais com redução das suas capacidades em ambos os membros, porém apresentavam maior simetria entre os membros. Por outro lado, pacientes submetidos à RLCA com o autoenxerto ipsilateral apresentaram assimetrias importantes, embora tenham atingido melhores resultados para EAVD e Lysholm. Os resultados desta pesquisa contribuem na busca por novos caminhos para o tratamento dos pacientes com lesões do LCA, no entanto, novos estudos devem ser desenvolvidos para que se potencializem os benefícios do processo cirúrgico e da reabilitação deste grupo.

Palavras-Chave: Ligamento Cruzado Anterior. Lesões do Ligamento Cruzado Anterior. Ligamento patelar. Autoenxerto Osso-Tendão Patelar-Osso. 


\section{LISTA DE FIGURAS}

1. Figura 1. Retirada e preparação do enxerto no joelho doador ......................... 13

2. Figura 2. Retirada e preparação do enxerto no joelho doador........................ 13

3. Figura 3. Artroscopia do joelho receptor durante o processo de reconstrução do

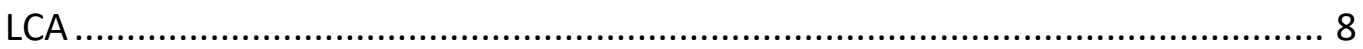

4. Figura 4. Início da fisioterapia pós-operatória ................................................. 15

5. Figura 5. Início da fisioterapia pós-operatória ................................................15

6. Figura 6. Exercícios de mobilidade na fase pós-operatória................................. 16

7. Figura 7. Exercícios de mobilidade na fase pós-operatória................................ 16

8. Figura 8. Exercícios resistidos e sensório motores na fase pós-operatória ........ 16

9. Figura 9. Exercícios resistidos e sensório motores na fase pós-operatória ........ 16

10. Figura 10. Crioterapia na fase pós-operatória ............................................... 16

11. Figura 11. Abordagem inicial dos pacientes para identificação e anamnese .... 17

12. Figura 12. Inspeção e palpação dos joelhos ...................................................... 18

13. Figura 13. Avaliação da amplitude de movimento por meio da goniometria ... 18

14. Figura 14. Avaliação da amplitude de movimento por meio da goniometria ... 18

15. Figura 15. Avaliação da estabilidade objetiva do joelho com o KT $1000^{\text {TM }}$......... 19

16. Figura 16. Execução do Single Leg Hop Test................................................... 20

17. Figura 17. Execução do Single Leg Hop Test.................................................... 20

18. Figura 18. Execução do Y Balance Test............................................................. 21

19. Figura 19. Aquecimento na bicicleta ergométrica ......................................... 21

20. Figura 20. Posicionamento dos pacientes para avaliação do desempenho muscular por meio da Dinamometria Isocinética ............................................ 22

21. Figura 21. Cálculo do peso do membro e definição da amplitude de movimento. 22

22. Figura 22. Avaliação Isocinética dos movimentos de extensão e flexão do joelho à $60 \% / \mathrm{s}$ 


\section{SUMÁRIO}

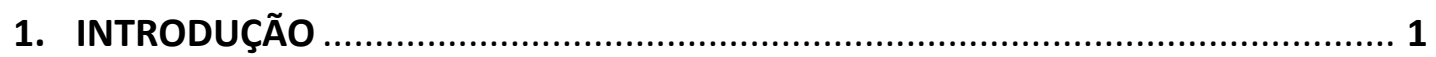

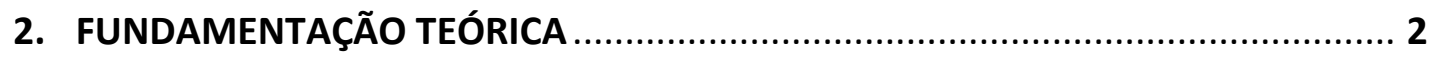

2.1 Estrutura e função da articulação do joelho ................................................ 2

2.2 Epidemiologia e fatores de risco da lesão do LCA .......................................... 4

2.3 Quadro Clínico e Diagnóstico..................................................................... 5

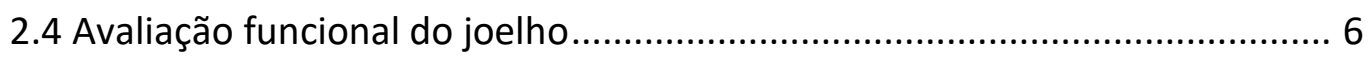

2.5 Questionários para avaliação funcional do joelho ........................................ 7

2.6 Avaliação Isocinética do joelho ................................................................ 8

2.7 Tratamento após a lesão do LCA ............................................................ 9

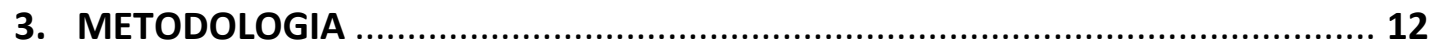

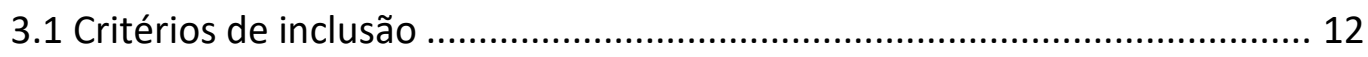

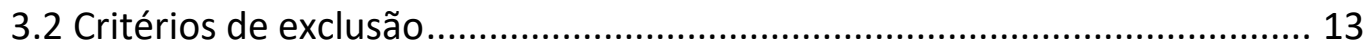

3.3 Instrumentos e procedimentos de coleta ................................................ 13

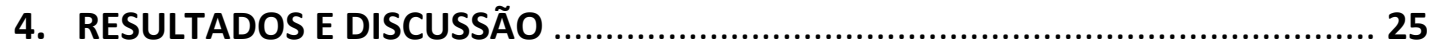

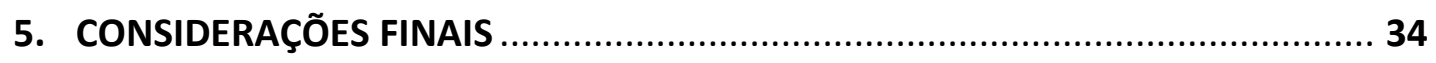

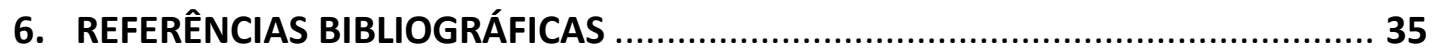

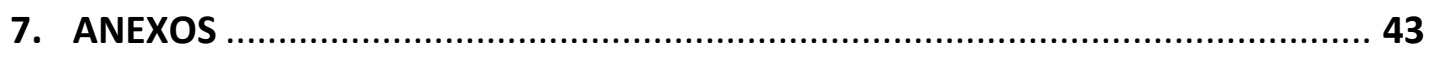

7.1 Termo de consentimento livre e esclarecido ............................................. 43

7.2 Ficha de avaliação clínica e funcional ...................................................... 46 


\section{INTRODUÇÃO}

As lesões do ligamento cruzado anterior (LCA) têm sido objeto de estudo desde o Século IX ${ }^{1}$. Segundo Mall ${ }^{2}$ e colaboradores, 200.000 reconstruções do LCA são realizadas anualmente nos Estados Unidos com custos diretos estimados em três bilhões de dólares. Lopes et $\mathrm{al}^{3}$ descreveram a incidência de reconstruções do LCA no Brasil no sistema público de saúde entre janeiro de 2008 e dezembro 2014, investigando as tendências temporais e diferenças entre os grupos de idade e gênero. Um total de 48,241 cirurgias foram reportadas no período, com incidência geral de 3,49 por 100.000 pessoas/ano. É considerada a lesão do jovem que pratica esporte e, com o aumento da população interessada na prática de atividade física, sua incidência tende a aumentar consideravelmente $e^{4,5,3}$.

Trata-se de uma ocorrência grave que acarreta uma série de complicações físicas, psicológicas e econômicas para o paciente ${ }^{6}$. No esporte pode significar a diminuição precoce do rendimento e até mesmo a interrupção da carreira do atleta ${ }^{7}$. Os joelhos com deficiência do LCA demonstram uma cinemática articular anormal durante a marcha e atividades funcionais, o que resulta em alterações degenerativas precoces ${ }^{8}$.

O tratamento do LCA deve levar em conta o tipo de paciente, sua atividade física e pretensões nesse sentido. Pode ser conservador ou cirúrgico, dependendo das condições anteriormente citadas.

Shelbourne e Urch ${ }^{6}$ relatam que a reconstrução do LCA é um procedimento cirúrgico comum entre os cirurgiões ortopédicos. Inicialmente era realizado em atletas que desejavam retornar ao nível de atividade e desempenho anterior à lesão. Devido ao resultado da melhora na técnica e bem como na propedêutica de reabilitação, passou a ser indicado também para a população de maior idade e fisicamente ativa.

Existem várias técnicas para reconstrução do LCA. A experiência do cirurgião, a viabilidade biológica do enxerto, a morbidade do sítio doador e as expectativas funcionais do paciente são fatores que devem ser considerados nesta escolha. Entre os enxertos disponíveis estão, os aloenxertos, enxertos sintéticos, o trato iliotibial, os tendões dos músculos semitendíneo, do grácil ou do quadríceps femoral, bem como o terço central do ligamento da patela (LP) $)^{9,10,11}$. 
Embora as técnicas convencionais de cirurgia e os princípios que norteiam a reabilitação já tenham sido estabelecidos, a escolha do enxerto ainda envolve grande controvérsia na literatura, especialmente devido ao surgimento de alternativas que levam a uma recuperação mais precoce e segura ${ }^{6,12}$. Nesse sentido, a utilização primária do enxerto autógeno do LP retirado do membro contralateral à lesão, associado à reabilitação precoce e bem orientada, tem se mostrado eficiente, desde que acompanhada da avaliação criteriosa, que envolve parâmetros objetivos e subjetivos, como o grau de frouxidão ligamentar residual, o nível funcional, as alterações da acuidade proprioceptiva, a presença de algumas complicações como a dor, o derrame articular e a limitação do movimento articular, o desempenho dos músculos da coxa e a satisfação do paciente $6,11,12,13$.

Diante do exposto, o presente estudo teve por objetivo avaliar e comparar de forma prospectiva, do ponto de vista clínico e funcional, pacientes submetidos a reconstrução do ligamento cruzado anterior, utilizando o autoenxerto do ligamento patelar ipsilateral ou contralateral.

\section{FUNDAMENTAÇÃO TEÓRICA}

\subsection{Estrutura e função da articulação do joelho}

A articulação do joelho é formada por três ossos: o fêmur, a tíbia e a patela ${ }^{13,14}$. A fíbula está indiretamente associada ${ }^{15} \mathrm{e}$, ocasionalmente, observa-se a fabela, um osso sesamóide localizado no tendão de origem da cabeça lateral do músculo gastrocnêmio ${ }^{15}$.

Sua estrutura articular é subdividida em três articulações: uma intermédia entre a patela e o fêmur (articulação patelofemoral); e duas outras, medial e lateral, entre os côndilos do fêmur e da tíbia (articulações tibiofemorais medial e lateral) ${ }^{13,15}$.

As superfícies superiores e achatadas dos côndilos da tíbia, que são as maiores superfícies que sustentam peso no corpo, são aprofundadas por cartilagens fibrosas, chamadas meniscos medial e lateral que, além de auxiliar a sustentação de peso na articulação, também contribuem para a lubrificação e participam do mecanismo de 
travamento do joelho' ${ }^{15}$.

A articulação é reforçada anteriormente pelo ligamento da patela, que se estende desde o ápice patelar até a tuberosidade da tíbia. Trata-se da continuação do tendão central do músculo quadríceps femoral ${ }^{16}$.

Fixado ao côndilo medial do fêmur e à tíbia, encontra-se o ligamento colateral medial (LCM), que possui fibras fixadas ao menisco medial, contribuindo assim para o cisalhamento do menisco em caso de estresse excessivo nesse ligamento. Fixados ao côndilo lateral do fêmur e à cabeça da fíbula, encontra-se o ligamento colateral lateral $(\mathrm{LCL})$, que protege a articulação de estresse de medial para lateral. Os ligamentos colaterais encontram-se tensionados na extensão e relaxados na flexão do joelho ${ }^{15}$.

Estabilidade articular adicional é proporcionada pela presença, na cavidade articular, dos ligamentos cruzados anterior e posterior (LCP), que se estendem diagonalmente da superfície superior da tíbia à extremidade distal do fêmur, entre os côndilos. São chamados cruzados porque seus trajetos literalmente se cruzam dentro do joelho ${ }^{16}$.

O LCA é a principal contenção contra a translação anterior da tíbia em relação ao fêmur. Frank e Jackson ${ }^{17}$ relataram que o ligamento fornece $85 \%$ da força de contenção ligamentar contra o deslocamento anterior na flexão de $30^{\circ}$ e de $90^{\circ}$. Além disso, desempenha outras funções como o controle dos estresses em varo, valgo e hiperextensão, agindo como um guia durante a flexão/extensão tibiofemoral. Devido a sua localização intercondilar, se houver um estresse em valgo no joelho flexionado, o LCA se torna uma contenção contra a rotação externa da tíbia. Também auxilia a controlar a rotação externa da tíbia.

O LCP é um ligamento com menos importância biomecânica quando comparado ao LCA. Sua função limita-se no controle da translação posterior da tíbia sobre o fêmur, além de ajudar a controlar os estresses em valgo, varo e hiperextensão. Seu papel no controle das forças de rotação parece ser mínimo ${ }^{16}$.

\subsection{Epidemiologia e Fatores de Risco da Lesão do LCA}


A lesão do ligamento cruzado anterior é considerada a lesão do jovem que pratica esporte. Principalmente em esportes de contato que envolvam saltos, desaceleração e rotações. Nas crianças, pelo mesmo tipo de trauma, ocorrem os deslocamentos epifisários e no adulto, as fraturas do platô tibial, pois a cartilagem hialina na vida adulta é propensa à calcificação.

Segundo Shelbourne, Vanadurongwan e Gray ${ }^{19}$, a maior parte das lesões ocorre em indivíduos do sexo masculino e são decorrentes de lesões esportivas. Isso é devido ao maior número de homens praticando atividades desportivas, quando comparados com as mulheres. Por outro lado, em atividades nas quais há participação igualitária de ambos os sexos, a probabilidade de uma lesão do LCA é maior em mulheres. A faixa etária mais prevalente está entre 15 e 45 anos de idade.

Diferenças na largura pélvica e no ângulo tibiofemoral entre homens e mulheres possivelmente afetam toda a extremidade inferior. A magnitude do ângulo $Q$ e a largura da região intercondilar femoral são considerados possíveis fatores anatômicos que contribuem para a disparidade dos índices de lesão do LCA entre homens e mulheres ${ }^{16}$.

Alguns estudos demonstram que a lassidão articular tende a ser maior em mulheres do que em homens, embora a relação entre essa condição e a lesão do LCA não esteja clara $^{19}$.

As mulheres em geral possuem o LCA menor que o dos homens, o que ocasiona o aumento do risco de falha do tecido. Além disso, acredita-se que o posicionamento muito próximo da parede intercôndilo pode contribuir para o maior risco de lesão ${ }^{16}$.

Aproximadamente $30 \%$ das lesões do LCA são resultados de contato direto com outro participante ou objeto, sendo os restantes $70 \%$ não resultantes de contato direto e com os mecanismos de lesão ainda em debate ${ }^{20}$.

O mecanismo mais frequente de lesão do LCA é o trauma torcional. Nesse caso, o corpo gira em rotação externa sobre o membro inferior apoiado no solo. Outros mecanismos são a força lateral excessiva (estresse em valgo) aplicada na região exterior da articulação, característica em esportes de contato, e a hiperextensão do joelho sem apoio ${ }^{8}$.

\subsection{Quadro Clínico e Diagnóstico}


No trauma agudo, o paciente geralmente percebe um estalido seco no joelho, o qual é associado a derrame imediato. O estalido acompanha $85 \%$ das lesões do LCA, sendo referido nesse percentual pelos pacientes. O derrame imediato é de sangue, por lesão do ligamento em si ou da sinóvia que o recobre. Esses dois dados da história são determinantes para o diagnóstico ${ }^{8}$. A lesão do LCA determina uma frouxidão no joelho. Esse joelho frouxo torna-se instável e essa instabilidade inicialmente se faz presente na atividade esportiva e, depois, nas atividades da vida diária ${ }^{8}$. O Teste de Lachman é padrão ouro no exame clínico para avaliar a lesão do LCA $^{21}$. O KT1000 ${ }^{\mathrm{TM}}$ permitirá quantificar numericamente a frouxidão do ligamento ${ }^{22}$.

Na história do acidente, deve-se reproduzir o mecanismo de lesão e verificar se no trauma agudo houve o estalido (sugestivo de lesão do LCA), se o derrame foi imediato (hemorrágico) ou tardio (sinovite reacional) e se houve incapacidade funcional ${ }^{8}$.

A literatura reconhece que o derrame articular imediato representa lesão do LCA em $80 \%$ ou mais dos casos. Deve-se lembrar que $30 \%$ das lesões agudas do LCA podem ocorrer sem dor e $15 \%$ dos pacientes podem continuar praticando esporte. Em alguns casos de lesão do LCA no futebol, o atleta tem condições de terminar a partida, sem precisar sair de campo?.

O paciente deve relatar o primeiro atendimento, as medidas tomadas e, em seguida, analisar a evolução de sintomas no tempo decorrido até a consulta, se voltou a praticar esporte e em que condições. Deve-se investigar a época em que se iniciaram os falseios e as situações nas quais ocorreram, se na atividade esportiva ou na vida diária e também procurar determinar se houve lesão meniscal associada com os seus bloqueios e travamentos e, em caso afirmativo, quando essa lesão ocorreu ${ }^{8}$.

A atrofia do quadríceps é um achado quase constante em pacientes que têm o LCA rompido ${ }^{24}$, como também a diminuição no torque extensor ${ }^{25}$ ou flexor ${ }^{26}$ dependendo do tipo do enxerto. O comprometimento das capacidades sensório motoras também são comuns ${ }^{27}$, além das perdas de amplitude de movimento (ADM) tanto para flexão quanto hiperextensão do joelho ${ }^{28}$.

Radiografias devem ser feitas como em todos os casos de traumatizados. Especificamente no joelho, elas são fundamentais para afastar fraturas articulares, deslocamentos epifisários ou para detectar pequenos arrancamentos que poderão caracterizar lesões de natureza mais grave ${ }^{28,8}$. Entretanto, a ressonância magnética 
(RM), quando bem interpretada, traz dados interessantes no estudo da patologia dessa lesão. É o padrão ouro dentre os exames de diagnóstico da ruptura do LCA e seu índice de precisão gira em torno de $94 \%{ }^{28}$.

\subsection{Avaliação funcional do joelho}

As deficiências de controle neuromuscular e risco de futuras lesões têm sido avaliadas por meio de testes de salto, aterrissagem e equilíbrio unipodal, além de avaliações de padrões de movimento ${ }^{29}$,

O Y Balance Test (YBT) é uma variação instrumentada do Star Excursion Balance Test (SEBT), que tem por objetivo investigar a performance durante o equilíbrio unipodal ao alcançar três direções: anterior, póstero-lateral e póstero-medial, visando determinar assimetrias de extremidades inferiores e déficits de equilíbrio. Se trata de um teste rápido, prático e que gera resultados objetivos em relação a assimetrias e instabilidades entre membros.

Conforme Gonell et al. $^{30}$, assimetrias e índices fora do esperado para determinado perfil indicam que uma disfunção no sistema neuromuscular pode estar presente, o que pode levar a maior probabilidade de lesões do LCA sem contato. Ainda Segundo o estudo de Smith et al. ${ }^{29}$, assimetrias maiores ou iguais a $4 \mathrm{~cm}$ em alcance anterior apresentaram maior risco para lesões quando comparado com aqueles que obtiveram assimetrias menores.

O Single Leg Hop Test (SLHT) é um dos métodos que visa avaliar e comparar assimetrias e estabilidade entre membros, predizendo uma possível alta e retorno ao esporte. Durante o salto unipodal horizontal, o paciente é orientado a se equilibrar em uma perna e saltar o mais longe possível e se possível, realizar o teste com as duas pernas, visando uma comparação entre membros e análise de assimetrias.

Como base para avaliação de assimetrias entre membros do paciente, visando analisar força, função e mobilidade, é utilizado o Limb Symmetry Index (LSI) que consiste em um guia para mensuração objetiva de discrepâncias. O resultado do LSI é dado em porcentagem e considerado satisfatório acima de 90\%. De acordo com Wellsandt et al. ${ }^{31}$, esse método de comparação tem superestimado a função do joelho após a 
reconstrução do LCA (RLCA) e tem estado relacionado a uma possível re-ruptura ligamentar.

Benjaminse et al. ${ }^{32}$ também indicam que os critérios de alta com base nos dados de LSI obtidos através doo SLHT devem ser utilizados com cautela quando utilizados como critério primário para retorno ao esporte após uma reconstrução do ligamento cruzado anterior. Ainda segundo os autores, mesmo que alcancem a simetria entre membros, pacientes que não alcancem os índices pré lesão apresentam um maior risco de uma segunda lesão do LCA, visto que os dados SLI subestimam a performance e déficits funcionais.

\subsection{Questionários para a avaliação funcional do joelho}

Na busca pela melhor escolha de tratamento, é necessário realizar uma avaliação que quantifique a lesão e suas consequências, com esse objetivo são aplicados questionários para avaliar a função, dor e instabilidade do joelho. Para Briggs et al. ${ }^{33}$, o questionário de Lysholm é indicado para avaliar os sintomas de instabilidade, e para Colins et al. ${ }^{34}$ a escala de atividades de vida diária (EAVD) é indicada para determinar os sintomas e a limitação funcional nas atividades diárias habituais causadas por várias patologias. A escala analógica visual de dor quantifica a dor do paciente.

Descrito pela primeira vez em 1982, o questionário de Lysholm tem como objetivo principal avaliar as condições dos joelhos em lesões de ligamentares, enfatizando a avaliação dos sintomas de instabilidade ${ }^{35}$. A escala de Lysholm, é um questionário simples que inclui oito itens sobre a função do joelho e sintomas na vida diária, uma pontuação entre 91 e 100 pontos significa um excelente resultado, uma pontuação de 84 a 90 pontos é um bom resultado, com pontuações entre 65 e 83 pontos, indicando um resultado regular e pontua $<64$ pontos, um resultado ruim $^{36}$. De acordo com $\mathrm{Ra}^{37}$, é um dos mais amplamente utilizados em pesquisas e em campo clínico. Em 2006, o questionário foi validado para a língua portuguesa ${ }^{38}$.

De acordo com Szczepanik ${ }^{39}$, a EAVD avalia os sintomas e as limitações durante as atividades de vida diária. A escala é dividida em duas partes, a primeira conta com 6 itens que avaliam os sintomas (dor, rigidez, inchaço, instabilidade, fraqueza e mancando), a segunda conta com 8 itens avaliando as limitações funcionais do indivíduo 
(caminhar, subir e descer escadas, ficar em pé, agachar, ajoelhar, dobrar o joelho em 90으, levantar da cadeira). É um questionário amplamente utilizado na área e foi validado para o português em $2008^{40}$.

Existem diversas escalas para avaliar a dor (1) As multidimensionais avaliam a dor em toda a sua complexidade, como localização, duração, intensidade; (2) As unidimensionais são mais práticas e por isso mais utilizadas, elas abrangem apenas a intensidade da dor ${ }^{41}$. A escala analógica visual de dor (EVA), é uma escala unidimensional, que consiste em uma linha numerada de 0 a 10 , onde em uma extremidade é colocado "nenhuma dor" e na outra extremidade "pior dor imaginável", então é solicitado ao paciente que ele assinale a intensidade de sua dor. As escalas de dor são muito subjetivas e dependem de diversos fatores pessoais, todavia são escalas validadas e confiáveis para a mensuração de dor ${ }^{42}$.

\subsection{Avaliação Isocinética do joelho}

O conceito isocinético foi desenvolvido nos anos de 1960, e começou a ser amplamente utilizado nos anos 1980, devido ao aumento das evidências que demonstravam sua eficácia na avaliação e reabilitação dos pacientes com lesões nos joelhos ${ }^{43}$.

A avaliação isocinética do joelho, pode utilizar velocidades angulares que variam. Para o melhor estudo do pico de torque e do trabalho, utiliza-se velocidade angular do tipo lenta $(60 \% / \mathrm{s})$, pois quanto menor a velocidade angular maior é o torque ou o trabalho. Já para a avaliação da potência, costuma-se usar velocidades de $180^{\circ} / \mathrm{s}$ a $300^{\circ} / \mathrm{s}^{44}$.

Vários protocolos específicos para testar determinados parâmetros em diferentes populações são propostos na literatura ${ }^{45,46}$. No entanto, é certo que fatores como o aquecimento da musculatura, treinamento prévio, posição e estabilização do sujeito, amplitude de movimento, tempo de descanso entre as séries, incentivo verbal e especificações do aparelho podem, influenciar os resultados obtidos e levar a erros na sua interpretação ${ }^{47,48}$.

Os parâmetros de análise da avaliação isocinética em pacientes pós-cirúrgicos do LCA incluem: (1) O pico de torque ou momento de força, que é o ponto de maior torque 
na amplitude de movimento; (2) O trabalho total, representando a energia total realizada no esforço muscular durante o movimento; (3) A relação de equilíbrio agonista/antagonista, sendo a divisão entre do valor do músculo agonista e do antagonista, seja relacionado ao pico de torque, trabalho ou potência ${ }^{49}$.

É na avaliação funcional, como em todo aparelho locomotor, que o dinamômetro isocinético apresenta seu ponto estratégico de aplicação, constituindo-se num importante método auxiliar para tal investigação ${ }^{44}$. Diversos estudos demonstram correlações positivas entre os resultados da avaliação isocinética e o desempenho funcional de pessoas com e sem lesão nos joelhos. Patel et al. ${ }^{50}$ realizou o teste isocinético com 44 indivíduos saudáveis e 44 indivíduos com lesão do LCA. O grupo com lesão apresentou força de quadríceps significativamente menor que o grupo controle, 0 que foi relacionado a diminuições importantes do momento de força do quadríceps durante atividades de corrida, salto ou subir escadas.

Karanikas et al. ${ }^{51}$ Correlacionou os achados entre a força muscular isocinética e a cinemática da marcha e corrida após a reconstrução do LCA. Os resultados mostraram que pacientes com déficits significativos de força também demonstraram estratégias anormais de cinemática da locomoção. Laudner et al..$^{52}$ investigou os resultados de testes de salto e avaliação de força em 33 pacientes após 6 meses de reconstrução do LCA. O desfecho do estudo indicou que o desempenho dos voluntários durante os testes de salto unilaterais, bilaterais e saltos consecutivos apresentaram correlações positivas com as medidas de força isocinética dos joelhos.

\subsection{Tratamento após a lesão do LCA}

Os cuidados para a lesão do LCA são de suma importância, considerando que se trata de uma lesão altamente debilitante, sobretudo para indivíduos fisicamente ativos. Pessoas com lesão do LCA podem ser submetidas à reconstrução cirúrgica do ligamento ou podem ter sua lesão tratada não cirurgicamente ${ }^{53}$.

Por um lado, o tratamento conservador é indicado para pessoas pouco ativas fisicamente e que não tenham apresentado instabilidade funcional do joelho ${ }^{54}$. Por outro lado, o argumento para a intervenção cirúrgica é que a estabilização do joelho com deficiência do LCA é necessária para prevenir futuras lesões em outras estruturas, 
incluindo o menisco e a cartilagem articular, o que poderia aumentar o risco de osteoartrite precoce ${ }^{55}$. Além disso, a RLCA apresenta bons resultados clínicos, sendo necessária para que os pacientes retornem à sua função de alto nível, permitindo, por exemplo, que cerca de dois terços dos atletas retornem ao esporte no mesmo nível prélesão ${ }^{56}$.

Com o advento da cirurgia artroscópica, as técnicas de reconstrução do LCA evoluíram consideravelmente, assim como a fisioterapia, que passou a ser realizada antes e após a cirurgia, promovendo resultados cada vez mais efetivos.

A reabilitação pré cirúrgica, descrita inicialmente por Noyes et al. ${ }^{57}$, é definida como a preparação do joelho, para um período de restrição de mobilidade e redução das atividades devido a cirurgia. Um bom programa de fisioterapia pré-operatória deve ser idealizado visando reduzir os episódios de falseio do joelho, que progressivamente trazem prejuízos à articulação ${ }^{58}$, bem como facilitar a recuperação no período pós cirúrgico, familiarizar o paciente com a rotina de exercícios após a reconstrução do ligamento e estabelecer uma relação importante entre o fisioterapeuta e o paciente ${ }^{58,59}$.

Poucos estudos têm se preocupado em explorar os efeitos da fisioterapia préoperatória nos resultados após a reconstrução do LCA. No estudo de Frobell et al. ${ }^{60}$, uma estratégia de reconstrução precoce do LCA junto a fisioterapia pós-operatória, em cinco anos, não foi mais eficaz do que uma estratégia de reabilitação inicial com a opção de reconstrução tardia do ligamento. Em uma investigação com 45 voluntários submetidos a reconstrução do LCA, Lepley e Palmieri-Smith ${ }^{61}$ identificaram que pacientes com melhores resultados pré-cirúrgicos de ativação muscular do quadríceps também apresentaram melhores resultados de ativação do quadríceps no período pósoperatório.

O LCA pode ser reconstruído por uma técnica cirúrgica extra-articular, intraarticular ou combinada. Os procedimentos extra-articulares estão sendo utilizados basicamente em adolescentes com uma epífise aberta, nos quais os túneis ossos não podem ser perfurados através destas para a colocação do enxerto intra-articular ou para complementar um procedimento intra-articular?

A seleção do enxerto ainda tem sido um tema de controvérsia e continua a ser altamente debatida. Entre os enxertos disponíveis estão, os aloenxertos, enxertos sintéticos, o trato iliotibial, os tendões dos músculos semitendíneo, do grácil ou do 
quadríceps femoral, bem como o terço central do ligamento da patela (LP) ${ }^{62}$.

Os programas de reabilitação pós-operatória evoluíram com o passar das décadas. Em 1982, Shelbourne e Nitz ${ }^{63}$ optavam pela imobilização do joelho por um período de 6 a 8 semanas após a reconstrução, porém, em 1983 adotaram um programa de reabilitação com o uso imediato do CPM (continuous passive moviment). Nos anos seguintes notaram que os pacientes que não obedeciam às etapas do programa de reabilitação recuperavam mais rapidamente as funções normais de seus joelhos, sem instabilidades. Posteriormente, baseados nessas observações, Shelbourne e Gray ${ }^{18}$ confirmaram, em um follow up de 2 a 9 anos pós-cirúrgico, vantagens da mobilização e fortalecimento precoces em um programa de reabilitação acelerada.

No contexto atual, para o período pós operatório, protocolos rigorosos baseados no tempo decorrido da cirurgia têm sido substituídos por diretrizes que contemplem critérios de alta e de retorno ao esporte ou return to play (RTP), dentre os quais pode-se citar:

(1) O controle dos sinais inflamatórios, que acabam por inibir o quadríceps. Spencer et. al (1984) identificaram que os mecanorreceptores na cápsula articular respondem a mudanças na tensão, inibindo os nervos motores que alimentam os músculos do quadríceps;

(2) A boa mobilidade articular do joelho, sobretudo para a sua extensão completa. A perda da extensão resulta em uma artrocinemática anormal das articulações tibiofemoral e patelofemoral, levando a pressões de contato anormais da cartilagem articular e inibição do quadríceps ${ }^{18}$;

(3) Reestabelecimento da ativação e força do quadríceps e isquiotibiais. Têm sido os critérios objetivos mais utilizado na determinação da prontidão do paciente para o RTP, estando relacionados a alterações na artrocinemática do joelho, que podem levar a osteoartite pós-traumática, e o risco de re-lesões ${ }^{65}$;

(4) Boa capacidade de reação neuromuscular, visando o aumento da estabilização dinâmica do joelho. $1 \%$ da área total do LCA é composto por receptores proprioceptivos, que fornecem informações aferentes quanto a posição e movimentos articulares. $\mathrm{Na}$ atualidade sabe-se que as lesões do LCA podem ser prejudiciais à capacidade sensóriomotora do joelho, o que pode levar a padrões anormais de movimento, que são um mecanismo para lesões posteriores e problemas secundários de longo prazo ${ }^{66}$. 


\section{METODOLOGIA}

Foi realizado um estudo longitudinal, prospectivo, cego com indivíduos submetidos a cirurgia de reconstrução do LCA com utilização dos autoenxertos do ligamento patelar ipsilateral (LPI) ou contralateral (LPC). As avaliações foram realizadas no Centro de Reabilitação do Hospital Ortopédico e Medicina Especializada - HOME, desde fevereiro de 2018 até agosto de 2019.

\subsection{Critérios de inclusão}

Foram incluídos no estudo pacientes de ambos os gêneros, com ocupações distintas, que praticavam atividade física regularmente, sofreram a lesão traumática aguda do LCA e foram submetidos a um tratamento comum. O programa envolveu a cirurgia de reconstrução com enxerto do ligamento da patela ipsilateral ou contralateral pela mesma equipe médica/procedimento e a fisioterapia pós-operatória até, no mínimo, o quarto mês após a cirurgia.

Para que a faixa etária de maior prevalência de lesões do LCA no Brasil ${ }^{3}$ fosse respeitada, somada à exclusão de menores de idade, todos(as) os participantes tinham a idade compreendida entre 18 e 55 anos.

\subsection{Critérios de exclusão}

Foram excluídos do estudo aqueles(as) que apresentavam dor ou outra restrição que os impedisse de realizar dos procedimentos de avaliação. Pacientes que não haviam completado a fisioterapia pós-operatória até o fim do 3o mês. Pacientes com histórico de lesões e(ou) cirurgia nos membros inferiores, cardiopatas, portadores de outras afecções de correlação sistêmica, gestantes/lactantes também foram dispensados(as). 


\subsection{Instrumentos e procedimentos de coleta}

Os pacientes foram encaminhados para a pesquisa ainda na fase pré-operatória, por meio da equipe médica, após terem sido diagnosticados e o tratamento em estudo ter sido definido como a opção primária. Todas as cirurgias foram feitas pela mesma equipe médica, que compõe o Departamento de Traumatologia Esportiva do Hospital HOME.

Em relação ao procedimento de retirada do enxerto doador, inicialmente realizou-se uma incisão no paratendão medial com divulsão por planos. A partir da abertura do peritendão, foram feitas marcações no ligamento da patela com $10 \mathrm{~mm}$ de largura, na patela e na tíbia de $20 \mathrm{~mm}$ de comprimento e retirados os plugs ósseos com $10 \mathrm{~mm}$ de profundidade com uma serra oscilatória. Após a retirada do enxerto, realizouse o fechamento da área doadora com fio de vicril 1.0, incluindo bainha e tendão. Dessa forma, colocou-se o enxerto ósseo na falha da patela (proveniente do túnel tibial do mesmo joelho receptor ou contralateral) ${ }^{6,67}$ (Figuras 1 e 2).
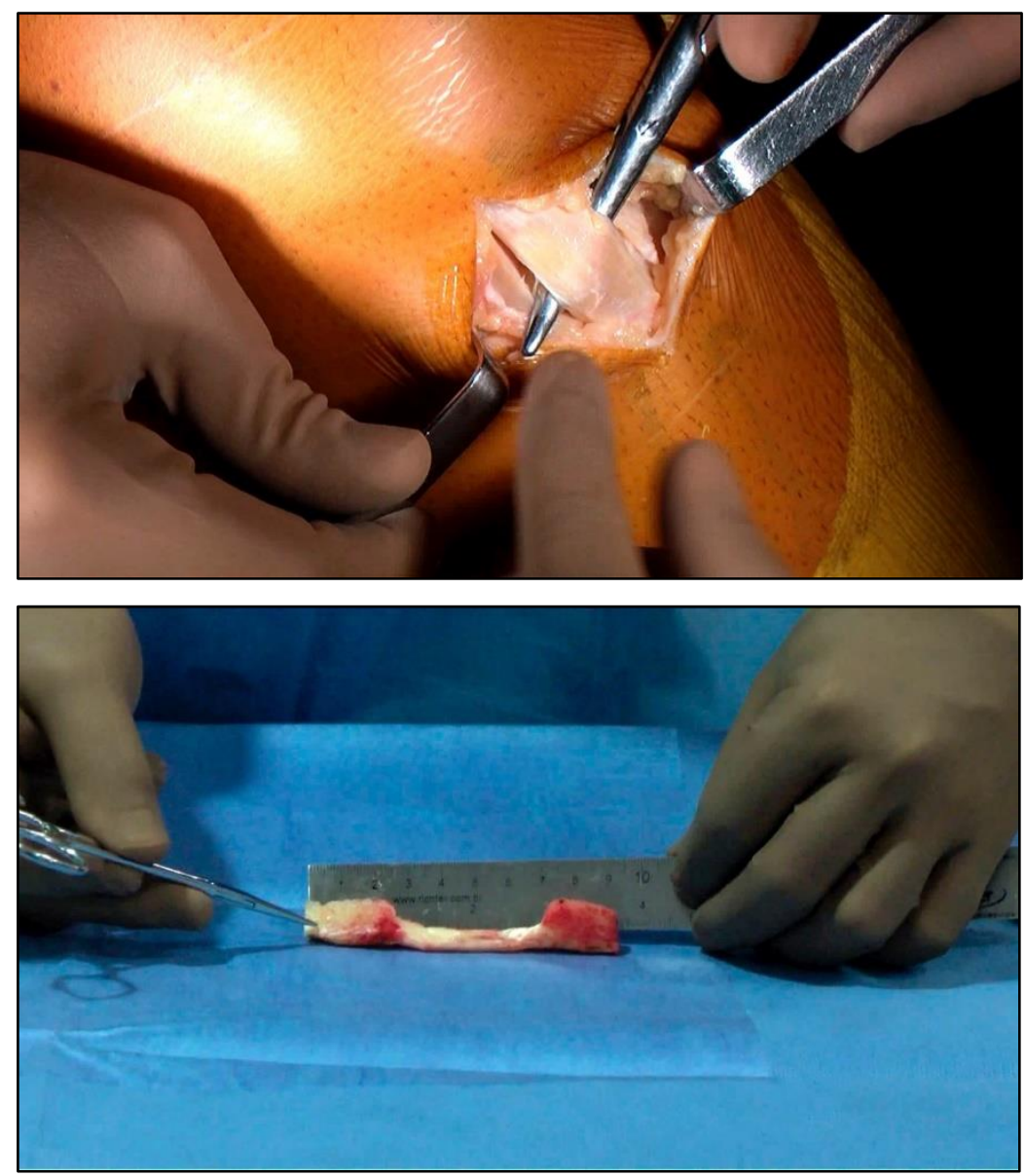

Fonte: Arquivo pessoal do autor (2019).

Figuras 1 e 2. Retirada e preparação do enxerto no joelho doador. 
Para alocação do enxerto retirado foram feitos os portais artroscópicos (Figura 3) e, em seguida, uma sinovectomia com limpeza do footprint da tíbia e do fêmur, seguindo o padrão da cirurgia artroscópica. O joelho foi então posicionado sobre a mesa cirúrgica em flexão de 120 graus. Pelo portal medial foi feito o túnel do fêmur, localizado aproximadamente entre as bandas ânteromedial e pósterolateral, um pouco mais medial, tentando reproduzir a banda AM. O túnel da tíbia é feito com o joelho fora da mesa e flexionado a 90 graus, utilizando um guia tibial. O footprint da tíbia se localiza na região medial do platô tibial, tendo como referência a borda posterior do corno anterior do menisco lateral. Após a medição dos túneis, o enxerto foi passado com o joelho flexionado em 45-90 graus, fixado no fêmur com endobutton CL BTB (Smith \& Nephew ${ }^{\circledR}$ ) e na tíbia com parafuso bioabsorvível (Smith \& Nephew ${ }^{\circledR}$ ) com o joelho em 0-20 graus de flexão. Por último, foi colocado o dreno intrarticular de sucção, feito a sutura de portais com fio nylon 4.0 e a sutura da incisão do joelho doador ${ }^{6,67}$.

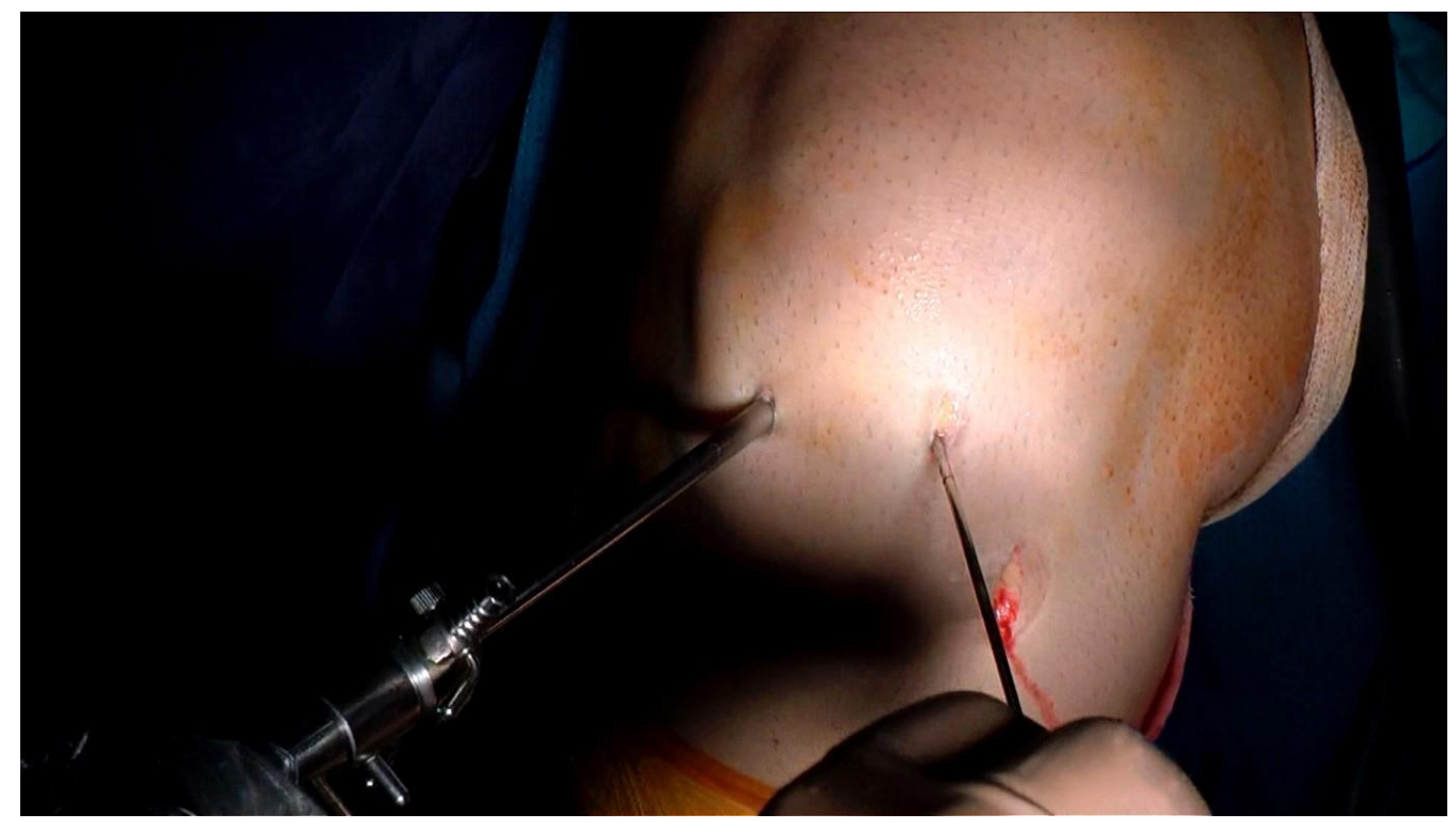

Fonte: Arquivo pessoal do autor (2019)

Figura 3. Artroscopia do joelho receptor durante o processo de reconstrução do LCA.

Quanto à fisioterapia pós-operatória, foi iniciada ainda no hospital durante o período de internação, no qual os pacientes foram orientados quanto a exercícios de mobilidade e ativação muscular, principalmente (Figuras 4 e 5). 

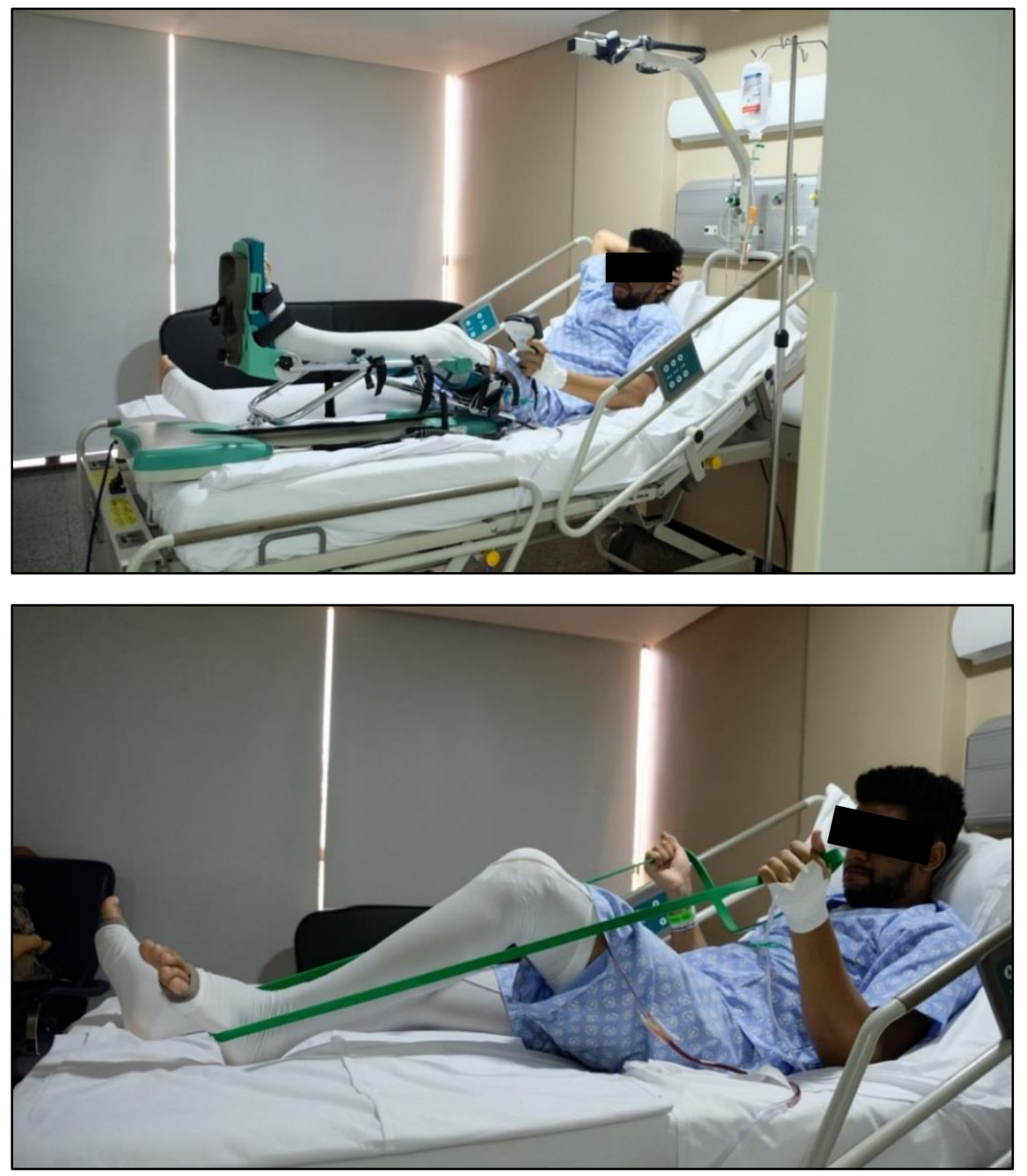

Fonte: Arquivo pessoal do autor (2019)

Figuras 4 e 5. Início da fisioterapia pós-operatória

Após a saída do hospital ( 24 horas de internação) e até o final da primeira semana, quando ocorre o primeiro retorno à equipe médica, os pacientes mantiveram os exercícios e condutas, anteriormente realizadas, em domicílio. Na fisioterapia ambulatorial, os pacientes foram acompanhados pela mesma equipe de fisioterapeutas, que tiveram como objetivo comum em suas condutas, eliminar a dor e hemartrose, restaurar a ADM e iniciar os exercícios de fortalecimento muscular junto à progressão sensório-motora (Figuras 6 a 10). Ao final do $3^{\circ}$ mês os pacientes se consultaram com seus médicos, responsáveis pela cirurgia, e foram liberados para a reavaliação. 

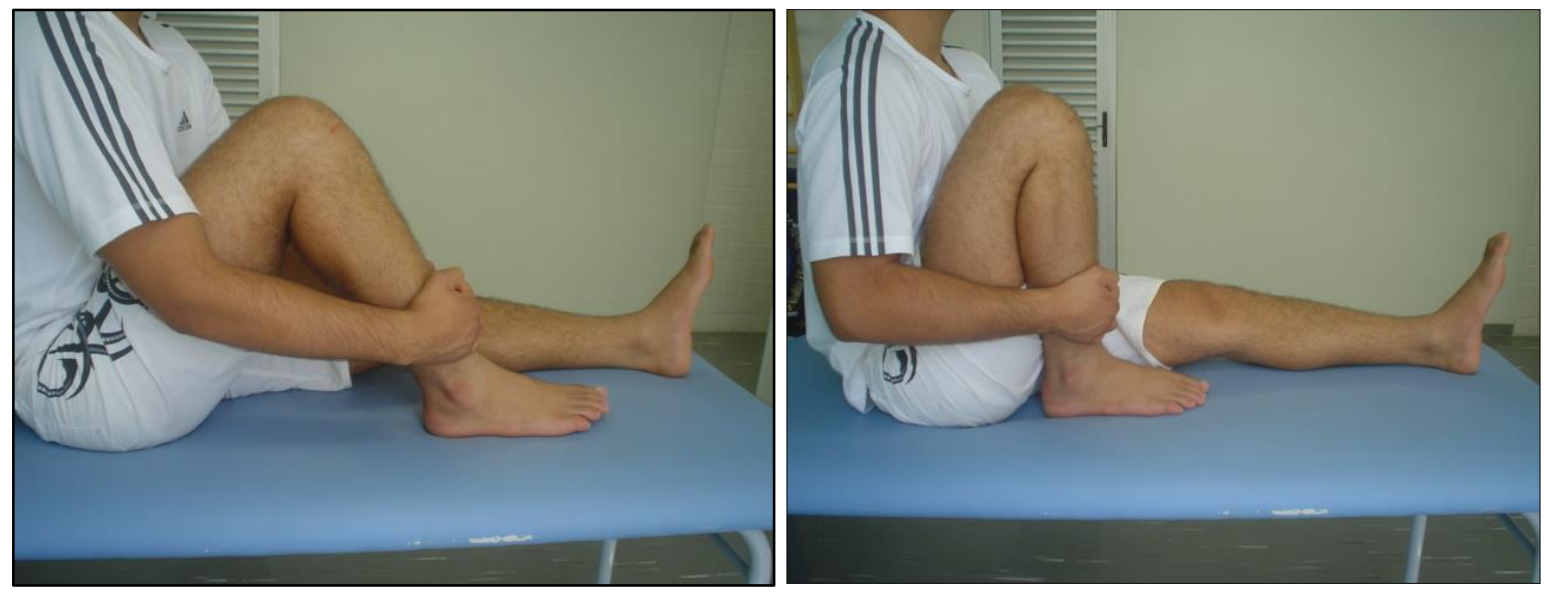

Fonte: Arquivo pessoal do autor (2019)

Figuras 6 e 7. Exercícios de mobilidade na fase pós-operatória
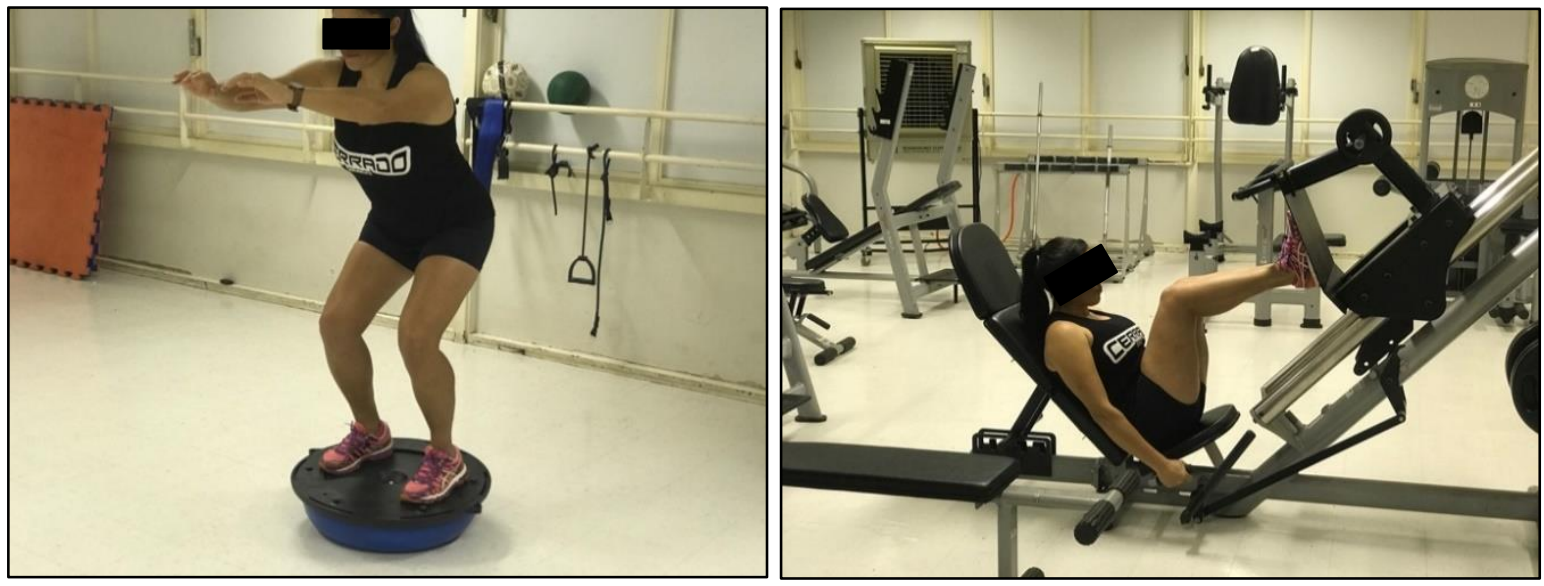

Fonte: Arquivo pessoal do autor (2019)

Figuras 8 e 9 . Exercícios resistidos e sensórios motores na fase pós-operatória

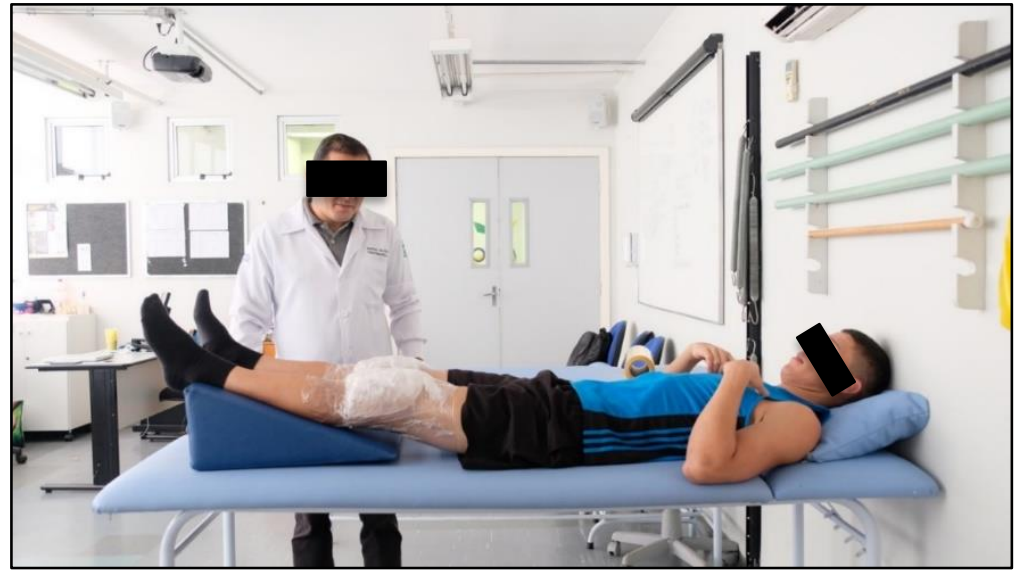

Fonte: Arquivo pessoal do autor (2019)

Figura 10. Crioterapia na fase pós-operatória

Somente as avaliações pós-operatórias foram realizadas de forma cega, por uma avaliadora independente, não envolvida com o estudo, sem vínculo empregatício com as instituições envolvidas, que foi contratada para este fim pelo Instituto de Pesquisa e 
Ensino do Hospital HOME - IPE/HOME. Era uma fisioterapeuta, pós-graduada em Fisioterapia Traumato-Ortopédica Funcional e Esportiva, com experiência na aplicação dos critérios utilizados e que desconhecia qualquer informação relacionada aos objetivos da pesquisa, diagnóstico dos pacientes e modo de distribuição da amostra.

Todos os voluntários foram orientados a não realizar qualquer tipo de atividade física nas 24 horas que antecedam os testes, para que houvesse descanso suficiente préavaliação, e usaram roupas de ginástica (camisa, short e tênis) durante os procedimentos. Os instrumentos utilizados encontravam-se calibrados de acordo com as orientações dos respectivos manuais.

Quanto as avaliações, tanto na fase pré quanto pós-operatória, inicialmente foram colhidas a identificação e anamnese do voluntário, com objetivo de conhecer, entre outras coisas, sua ocupação, esportes praticados, a história da lesão e possíveis outras lesões nos membros inferiores (Figura 11).

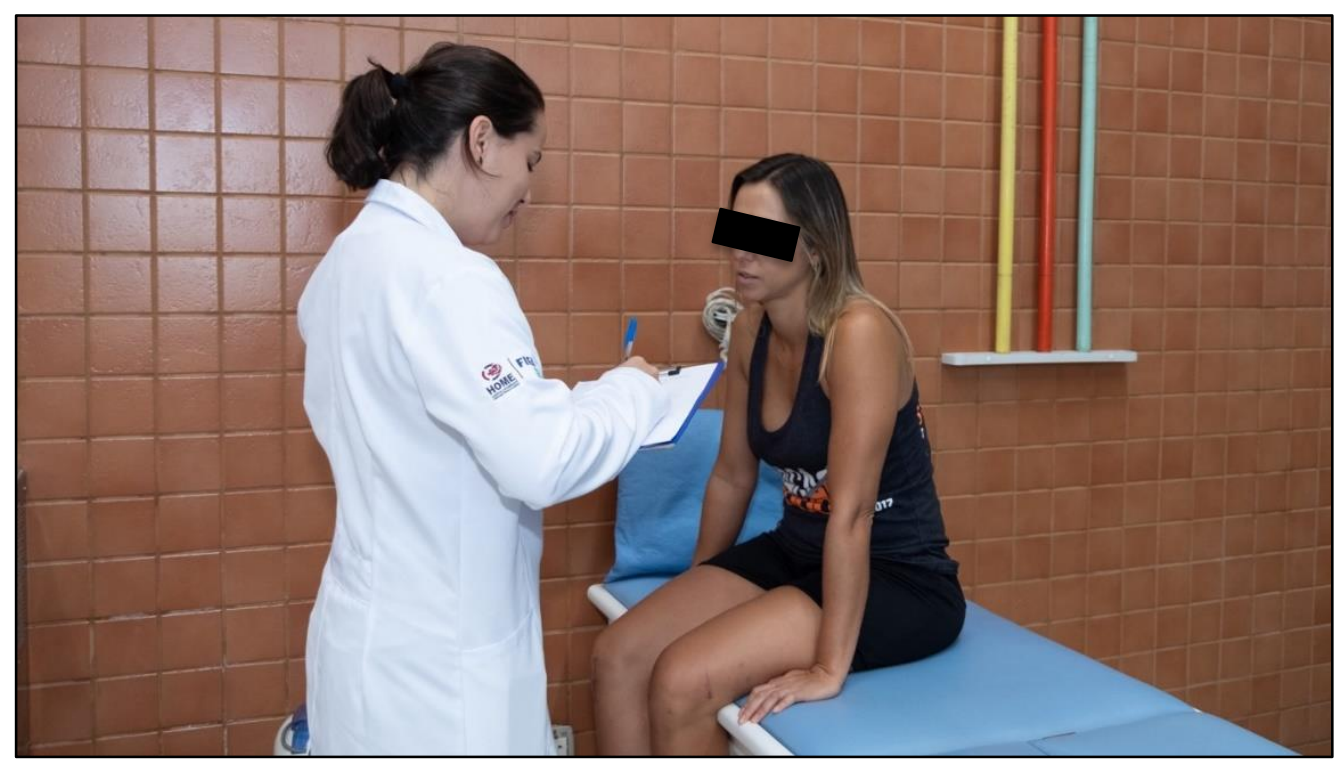

Fonte: Arquivo pessoal do autor (2019)

Figura 11. Abordagem inicial dos pacientes para identificação e anamnese

Iniciou-se a avaliação física com a inspeção e palpação dos membros inferiores, investigando a presença de edemas, alterações de temperatura, diferenças de tônus e trofismo e deformidades (Figura 12). Seguiu-se com a goniometria, na qual identificouse a amplitude de movimento passiva do joelho para flexão e hiperextensão (Figuras 13 e 14). O KT-1000 ${ }^{\text {TM }}$ foi utilizado para a avaliação da estabilidade articular objetiva (Figura 15). 


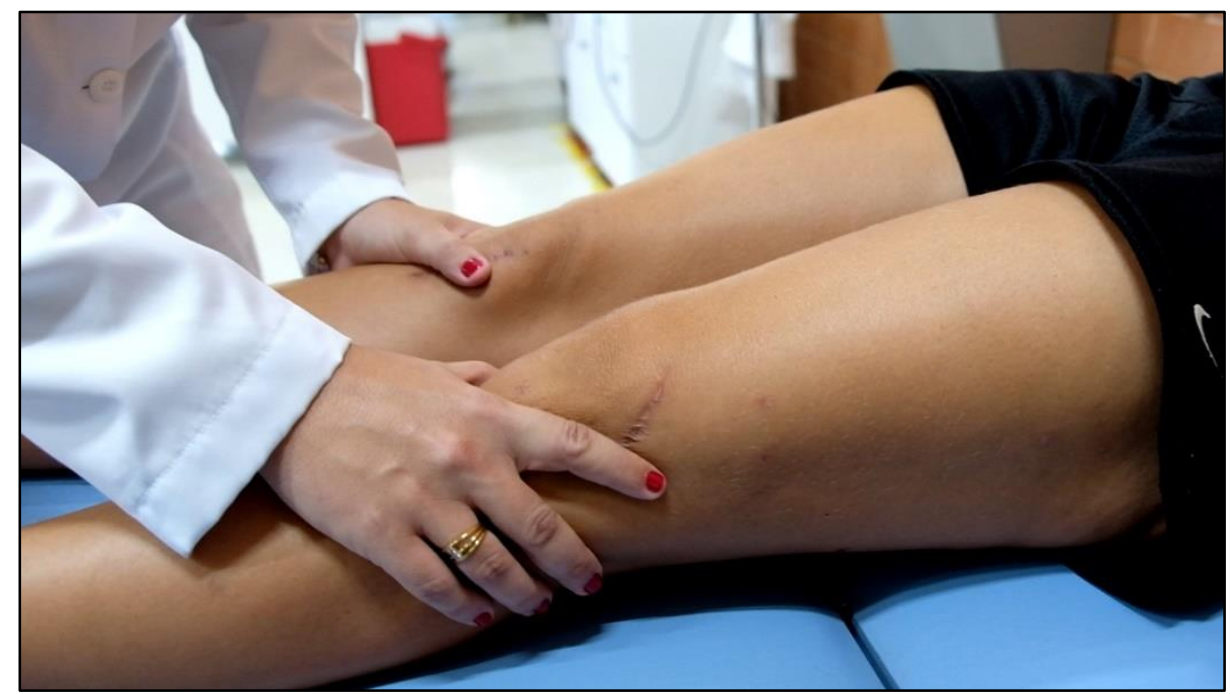

Fonte: Arquivo pessoal do autor (2019)

Figura 12. Inspeção e palpação dos joelhos
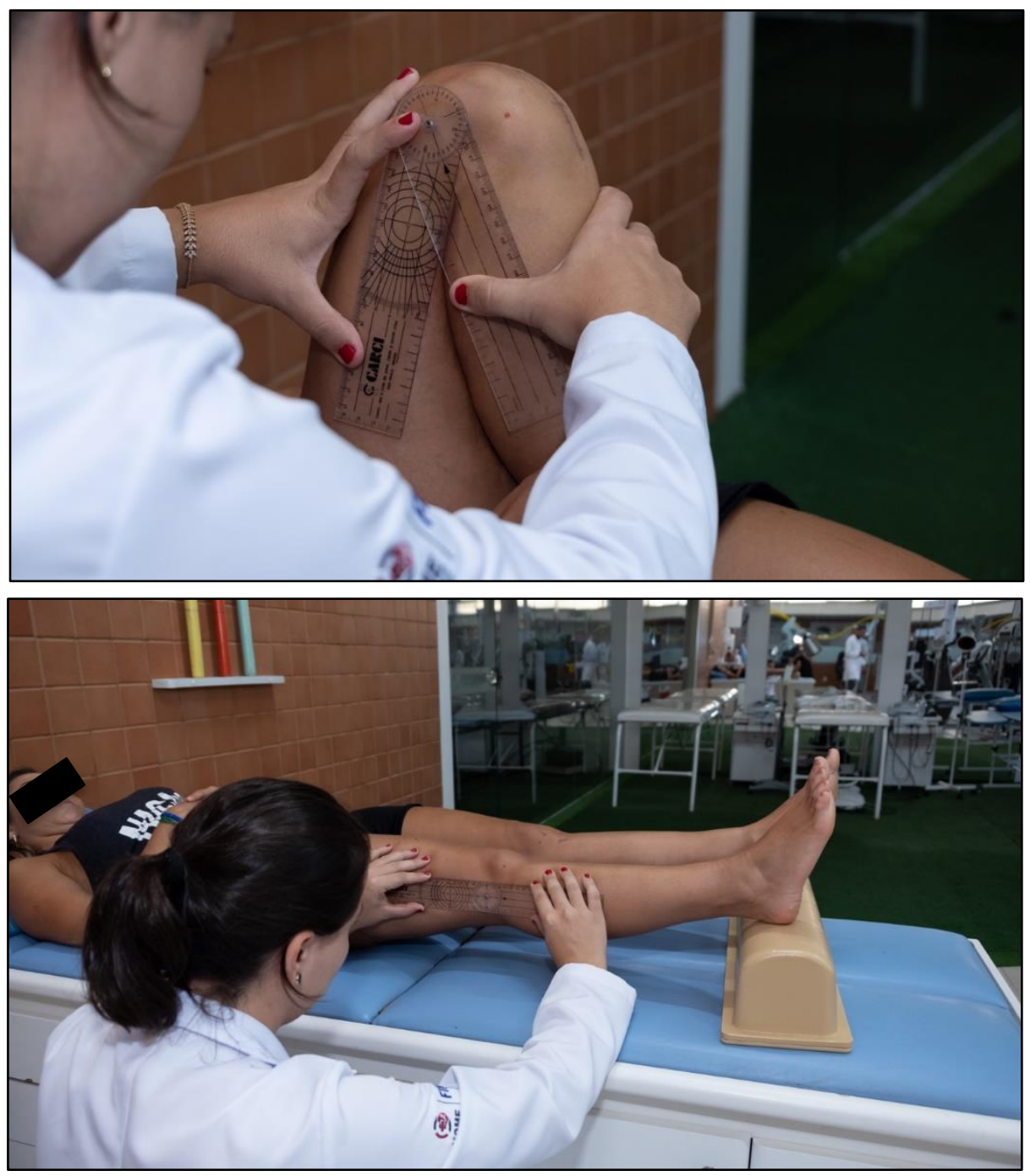

Fonte: Arquivo pessoal do autor (2019)

Figuras 13 e 14. Avaliação da amplitude de movimento por meio da goniometria 


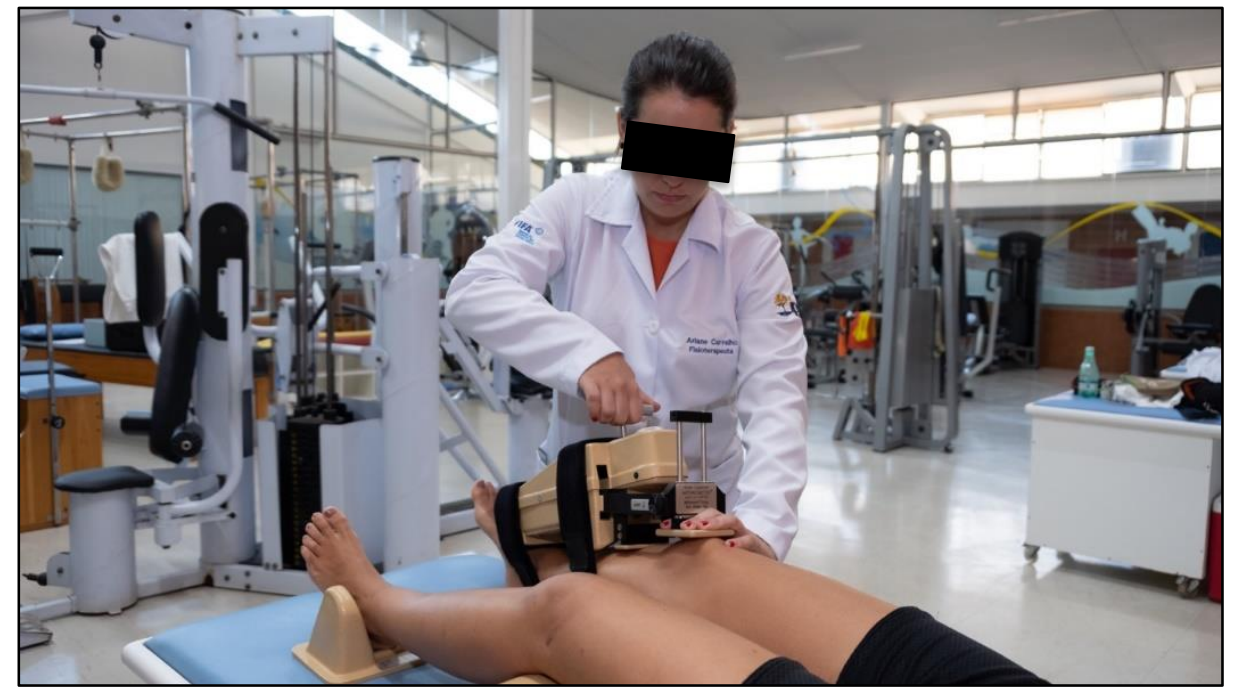

Fonte: Arquivo pessoal do autor (2019)

Figura 15. Avaliação da estabilidade objetiva do joelho com o KT $1000^{\text {TM }}$

Para a avaliação da capacidade sensório-motora dos indivíduos, foram utilizados dois testes funcionais: o Single-Leg Hop Test e o Y Balance Test. Previamente à execução de cada um dos testes, os sujeitos realizaram um ensaio de familiarização. No período pré-operatório, estes testes foram realizados somente com o membro sadio, visto o risco de suas execuções para o joelho lesionado ainda sem o enxerto de contenção. Ambos os membros foram avaliados no período pós cirúrgico.

No SLHT, os voluntários se equilibraram em apoio unipodal e foram instruídos a saltar a maior distância possível, de forma equilibrada, sem apoio do membro contralateral no momento de aterrissagem (Figuras 16 e 17). 0 teste foi realizado três vezes para cada membro, alternando entre direito e esquerdo. Mensurou-se a distância de cada salto em centímetros a partir da posição inicial do teste até o ponto de apoio. Considerou-se como valor do teste a média das três marcas alcançadas com cada membro. A movimentação livre dos braços durante o salto foi permitida, visando maior funcionalidade na sua execução. 

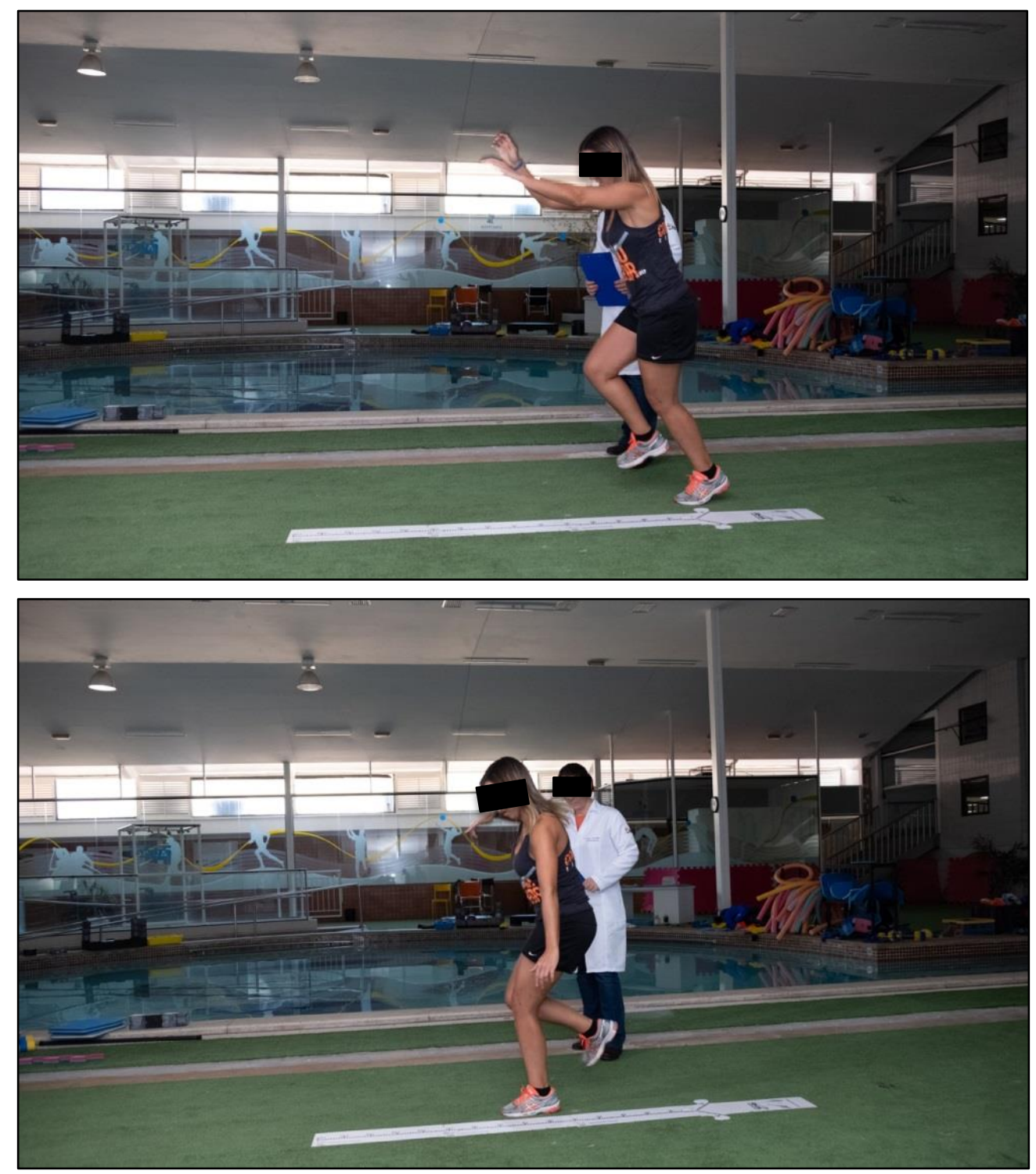

Fonte: Arquivo pessoal do autor (2019)

Figuras 16 e 17. Execução do Single Leg Hop Test

Durante a realização do YBT, os participantes permaneceram equilibrados em apoio unipodal, com o pé de apoio centralizado à intersecção das réguas enquanto o membro inferior contralateral alcançava a maior distância possível sobre as réguas, para as direções anterior, medial e lateral (Figura 18). As distâncias alcançadas foram medidas em centímetros pelo avaliador. Foram considerados como valores dos testes as distâncias máximas alcançadas para as três direções avaliadas. 


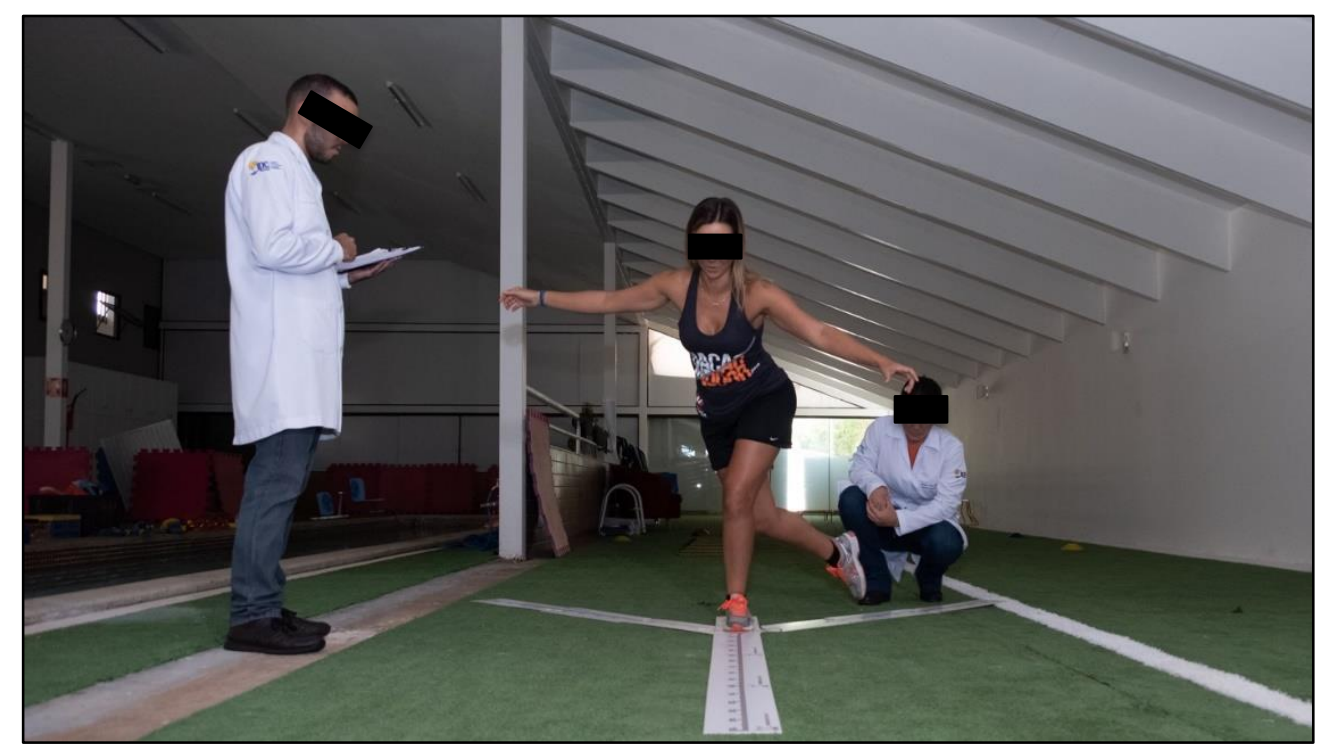

Fonte: Arquivo pessoal do autor (2019)

Figura 18. Execução do $Y$ Balance Test

Para a avaliação do desempenho muscular utilizou-se o dinamômetro isocinético Biodex System $4 \mathrm{PRO}^{\circledR}$. Inicialmente os(as) pacientes foram posicionados em uma bicicleta ergométrica vertical (Life Fitness modelo 95Ci) para aquecimento, sendo orientados a pedalar durante 10 minutos com uma carga de 50 Watts. Não foi prédeterminada a velocidade, apenas solicitou-se que mantivessem o movimento constante e sem esforço significativo (Figura 19)

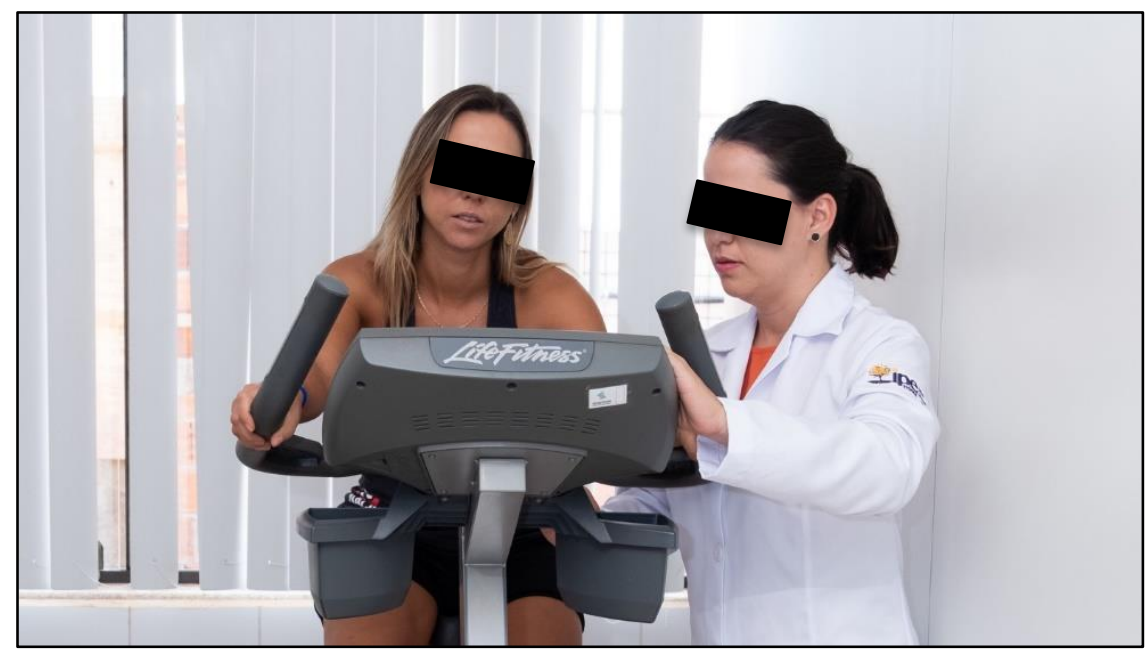

Fonte: Arquivo pessoal do autor (2019)

Figura 19. Aquecimento na bicicleta ergométrica

Os sujeitos foram avaliados na posição sentada e estabilizados por cintos no quadril, tronco e membro avaliado, o eixo do dinamômetro alinhado ao eixo articular a partir do epicôndilo lateral do fêmur e orientado o apoio das mãos nas cintas que 
passam pelo tronco (Figura 20). A unidade de aceitação de força (plataforma de resistência) foi fixada ao membro inferior, imediatamente superior ao maléolo medial.

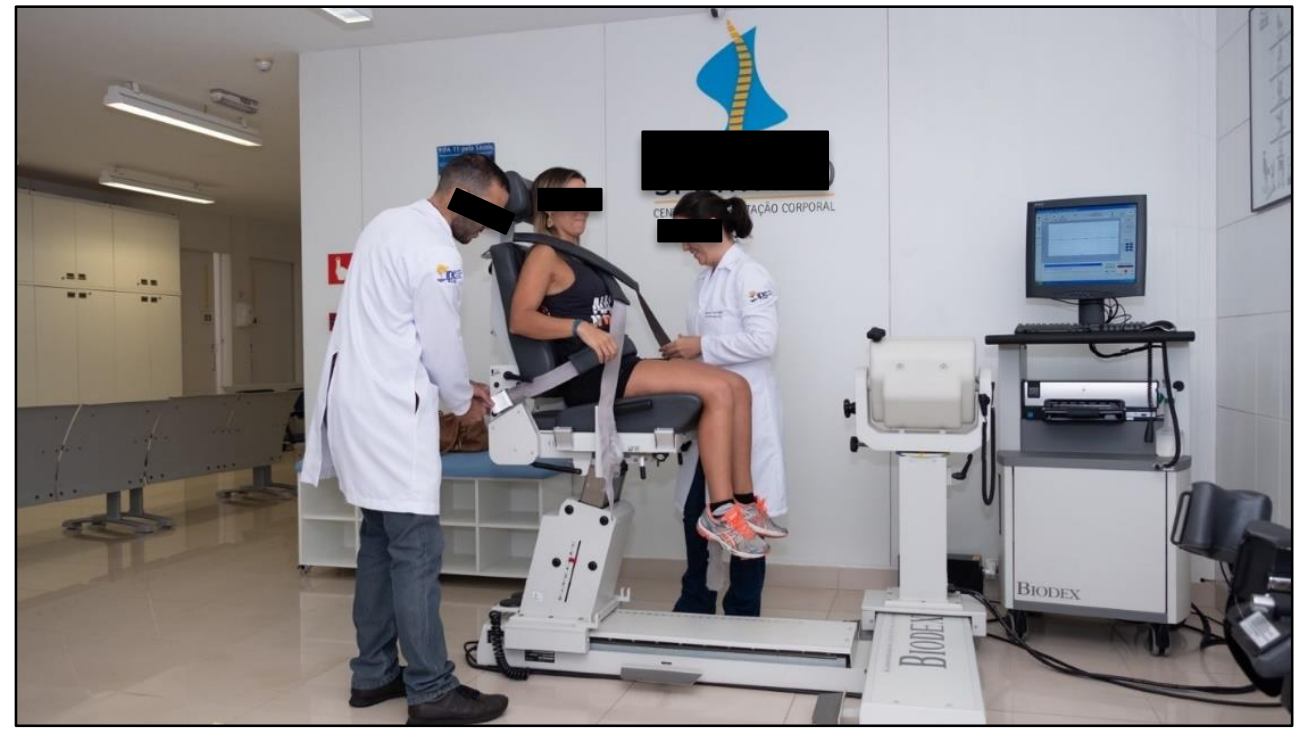

Fonte: Arquivo pessoal do autor (2019)

Figura 20. Posicionamento dos pacientes para avaliação do desempenho muscular por meio da Dinamometria isocinética

Após o posicionamento, foi determinado o movimento do teste e calculado o peso do membro a ser testado. A amplitude utilizada foi $90^{\circ}$. O cálculo do peso foi realizado ao final da ADM de extensão, quando, depois de atingida a posição, solicitavase aos pacientes o relaxamento completo do membro (Figura 21).

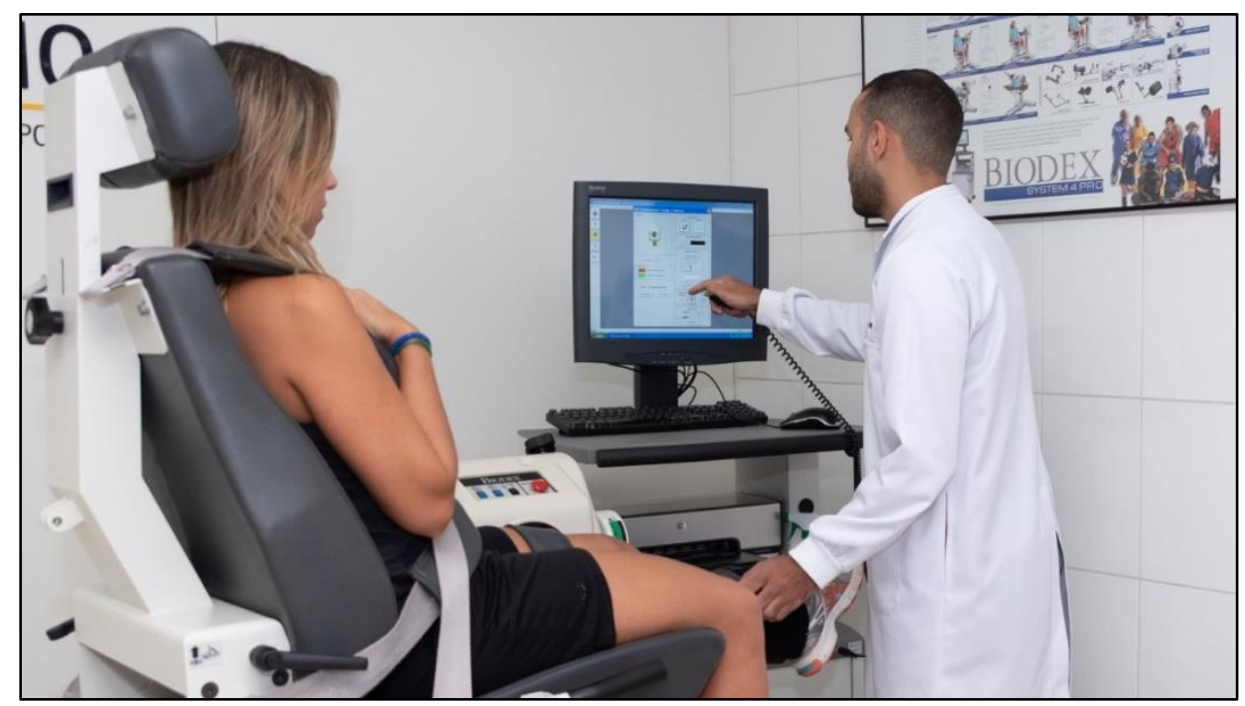

Fonte: Arquivo pessoal do autor (2019)

Figura 21. Cálculo do peso do membro e definição da amplitude de movimento. 
Anteriormente ao teste, os participantes realizaram cinco contrações submáximas na velocidade de 60\%/s apenas com o objetivo de familiarização com o equipamento, para posteriormente realizarem cinco repetições máximas concêntricas de quadríceps e isquiotibiais à velocidade de 60\%/s. Durante a execução do teste, foram encorajados a realizar força máxima a partir de estímulo verbal do avaliador e do feedback visual proporcionado pelo software do dinamômetro isocinético (Figura 22). Padronizou-se avaliar primeiramente o membro sadio/doador e posteriormente o membro lesionado/receptor.

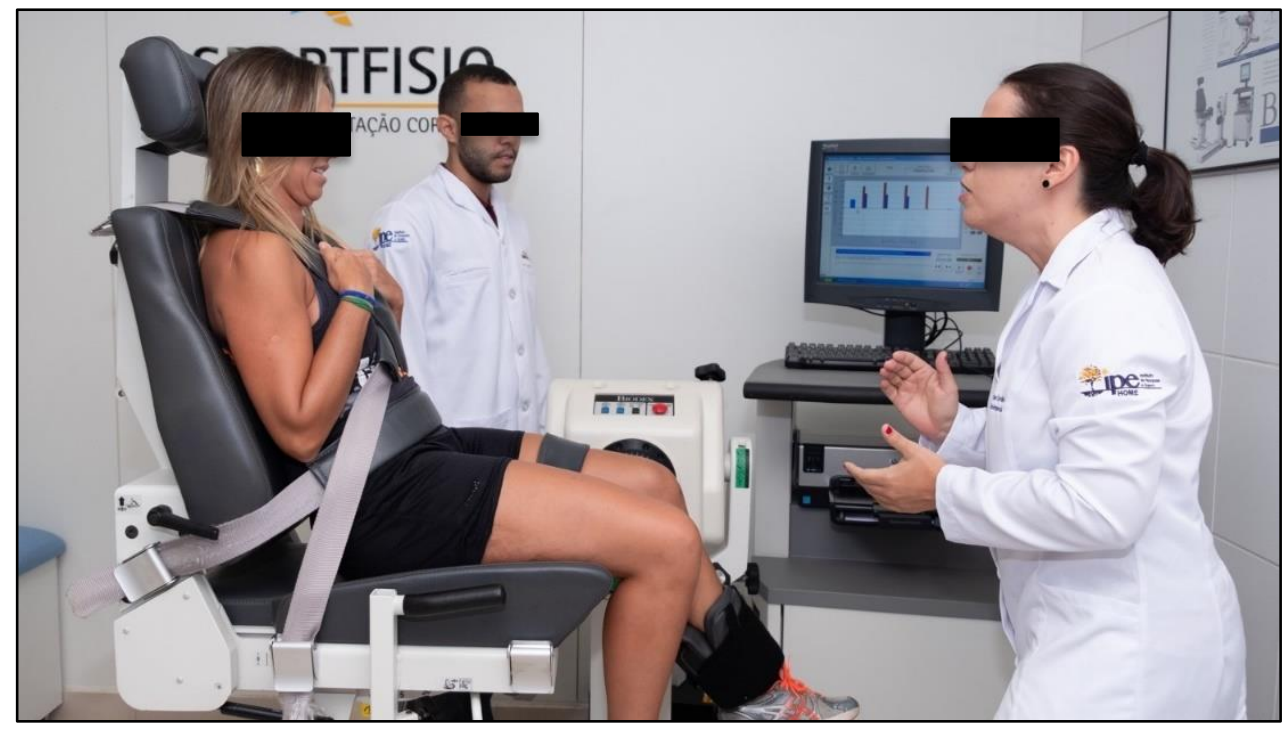

Fonte: Arquivo pessoal do autor (2019).

Figura 22. Avaliação isocinética dos movimentos de extensão e flexão do joelho à $60 \% / \mathrm{s}$.

Por último, foram aplicadas a Escala Visual e Analógica de Dor, a Escala de Atividades de Vida Diária e o Questionário de Lysholm, contidos na ficha de avaliação (ANEXO II). Além de registrado o tempo de retorno às atividades de vida diária.

A análise dos resultados do estudo foi feita de forma descritiva, utilizando-se medidas de tendência central (média), e medidas de dispersão (desvio padrão), bem como a variação percentual dos dados. Comparou-se o nível de simetria entre os membros dos dois grupos, quanto aos parâmetros objetivos de avaliação, além do nível funcional, para as variáveis subjetivas. Buscou-se também estabelecer quantitativamente a evolução de cada membro (sadio/operado e doador/receptor) entre os períodos pré e pós-operatório. 
Para fins de apreciação dos aspectos éticos implicados em pesquisas com seres humanos, este projeto foi submetido à avaliação e aprovado pelo Comitê de Ética em Pesquisa (CEP) do Centro Universitário de Brasília (UniCEUB), sob o número do CAAE: 76478517.0.0000.0023, conforme resoluções 196/96 do Conselho Nacional de Saúde / Ministério da Saúde. Previamente a qualquer avaliação, foi assinado pelos voluntários um termo de consentimento livre e esclarecido (TCLE), no qual os objetivos, procedimentos, riscos e benefícios da pesquisa foram claramente expostos (ANEXO I).

\section{RESULTADOS E DISCUSSÃO}

A amostra selecionada para o estudo foi composta por 54 indivíduos, dentre os quais, 27 (50\%) foram operados com o autoenxerto do LPI e 27 (50\%) foram operados com o autoenxerto do LPC. 48 indivíduos eram do gênero masculino ( 25 LPI e 23 LPC) e apenas 6 do gênero feminino (2 LPI e 4 LPC), como demonstrado do gráfico 1. Segundo Larson e Tailon ${ }^{69}$, como o número absoluto de homens em prática esportiva é maior, eles apresentam essa lesão mais que as mulheres. Por outro lado, em atividades nas quais há participação equânime de ambos os sexos, com regras e equipamentos similares (como é o caso do basquete e do voleibol), a probabilidade de uma lesão do LCA é 2 a 8 vezes maior nas mulheres ${ }^{69,70}$.

Gráfico 1: Gênero, conforme o grupo. Brasília - DF, 2019.

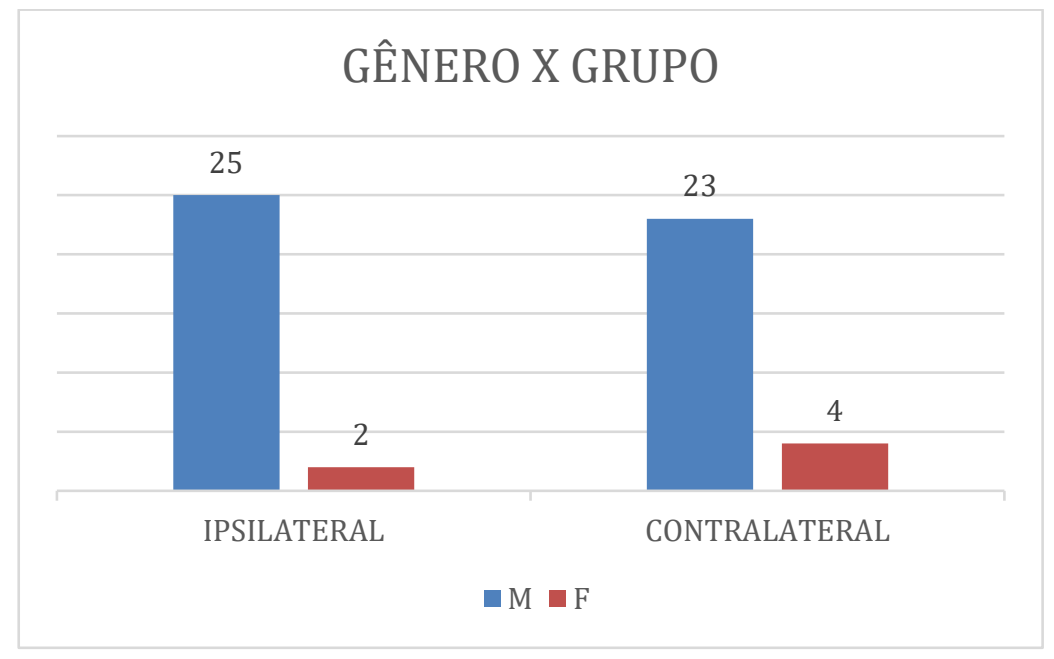


A média de idade entre os voluntários avaliados foi de $26,96( \pm 7,87)$ para o grupo contralateral e $24,59( \pm 6,58)$ para o grupo ipsilateral (tabela 1), consoante à faixa etária de maior prevalência de lesões do $\mathrm{LCA}^{2,71}$.

Tabela 1: Medidas Descritivas da idade (anos), peso (quilogramas) e estatura (centímetros), conforme o grupo. Brasília - DF, 2019

\begin{tabular}{|c|c|c|c|c|c|c|}
\hline GRUPO & \multicolumn{3}{|c|}{ CONTRALATERAL } & \multicolumn{3}{c|}{ IPSILATERAL } \\
\hline VARIÁVEL & IDADE & PESO & ESTATURA & IDADE & PESO & ESTATURA \\
\hline Média & 26,96 & 80,00 & 168,79 & 24,59 & 75,80 & 175,51 \\
\hline Desvio padrão & 7,87 & 14,50 & 33,98 & 6,58 & 13,30 & 7,33 \\
\hline
\end{tabular}

Dos 54 voluntários do estudo, 9 eram canhotos e 45 eram destros, todavia, o membro esquerdo foi o mais lesionado (28 lesões). Porém, quando analisados pela dominância, a diferença não foi muito grande. 31 indivíduos (57\%) sofreram a ruptura do LCA no membro dominante e 23 (43\%) tiveram a lesão no membro contralateral (gráfico 3). Não foram encontrados estudos que verificassem a relação entre lateralidade e/ou dominância na lesão do LCA.

Gráfico 2: Distribuição (\%) dos indivíduos pela lateralidade da lesão de acordo com a dominância. Brasília - DF, 2019 


\section{LATERALIDADE DA LESÃO DE ACORDO \\ COM A DOMINÂNCIA}

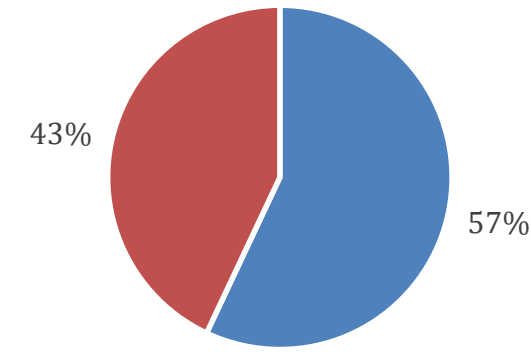

- Membro dominante - Membro contralateral

No período pré-operatório, observou-se, entre os dois grupos, homogeneidade da relação entre os membros no que diz respeito aos critérios objetivos avaliados. No geral, os dois grupos apresentavam as mesmas condições de simetria entre os membros (Tabela 2).

Tabela 2: Testes de comparação média entre os membros dos grupos contralateral e ipsilateral no período pré-operatório para os parâmetros objetivos. Brasília - DF, 2019

\begin{tabular}{|c|c|c|c|c|}
\hline \multicolumn{5}{|c|}{ CONTRALATERAL } \\
\hline \multirow{2}{*}{ PARÂMETROS } & \multirow{2}{*}{ MEMBRO } & \multirow{2}{*}{ MÉDIA } & DESVIO & DIFERENÇA \\
\hline & & & PADRÃO & NUMÉRICA \\
\hline \multirow{2}{*}{$\begin{array}{c}\text { ADM } \\
\text { hiperextensão }\end{array}$} & Doador & 7,25 & 2,55 & \multirow{2}{*}{0,92} \\
\hline & Receptor & 6,33 & 2,99 & \\
\hline \multirow{2}{*}{ ADM flexão } & Doador & 148,96 & 3,29 & \multirow{2}{*}{4,41} \\
\hline & Receptor & 144,55 & 7,32 & \\
\hline \multirow{2}{*}{ KT-1000 } & Doador & 4,4 & 2,2 & \multirow{2}{*}{3,7} \\
\hline & Receptor & 8,1 & 2,5 & \\
\hline \multirow{2}{*}{ PT extensão } & Doador & 235,8 & 47,9 & \multirow{2}{*}{34} \\
\hline & Receptor & 201,8 & 52,3 & \\
\hline \multicolumn{5}{|c|}{ IPSILATERAL } \\
\hline
\end{tabular}




\begin{tabular}{|c|c|c|c|c|}
\hline PARÂMETROS & MEMBRO & MÉDIA & $\begin{array}{l}\text { DESVIO } \\
\text { PADRÃO }\end{array}$ & $\begin{array}{l}\text { DIFERENÇA } \\
\text { NUMÉRICA }\end{array}$ \\
\hline \multirow{2}{*}{$\begin{array}{c}\text { ADM } \\
\text { hiperextensão }\end{array}$} & Sadio & 7,48 & 4,44 & \multirow{2}{*}{0,56} \\
\hline & Lesionado & 6,92 & 2,63 & \\
\hline \multirow{2}{*}{ ADM flexão } & Sadio & 147,55 & 4,37 & \multirow{2}{*}{4,37} \\
\hline & Lesionado & 143,18 & 7,86 & \\
\hline \multirow{2}{*}{ KT-1000 } & Sadio & 3,9 & 1,9 & \multirow{2}{*}{4,7} \\
\hline & Lesionado & 8,6 & 2,9 & \\
\hline \multirow{2}{*}{ PT extensão } & Sadio & 220 & 34,2 & \multirow{2}{*}{38,9} \\
\hline & Lesionado & 181,1 & 28,9 & \\
\hline
\end{tabular}

Para os parâmetros subjetivos, observou-se a maior diferença pré-operatória entre os grupos na Escala de Atividades de Vida Diária, tendo o grupo contralateral pontuado uma média numérica de $75,85( \pm 15,02)$ enquanto o grupo ipsilateral obteve a média de 70,37 ( \pm 19,16) (Tabela 3$)$.

Tabela 3: Médias EVA, EAVD e Questionário de Lysholm dos grupos contralateral e ipsilateral no período pré-operatório. Brasília - DF, 2019

\begin{tabular}{|c|c|c|}
\hline \multicolumn{3}{|c|}{ CONTRALATERAL } \\
\hline PARÂMETROS & MÉDIA & DESVIO PADRÃO \\
\hline EVA & 0,8 & 17,08 \\
\hline EAVD & 75,85 & 15,02 \\
\hline Lysholm & 78,33 & \\
\hline \multicolumn{3}{|c|}{ IPSILATERAL } \\
\hline PARÂMETROS & MÉDIA & 2,18 \\
\hline EVA & 1,18 & 19,16 \\
\hline EAVD & 70,37 & 18,77 \\
\hline Lysholm & 74,14 & DESVIO PADRÃO \\
\hline
\end{tabular}


Ao analisar a simetria entre os membros dos dois grupos no período pósoperatório, verificou-se que, quase sempre, a diferença numérica entre os membros para cada parâmetro avaliado foi maior no grupo ipsilateral, tendo o pico de torque extensor do joelho apresentado a maior discrepância, como demonstrado na tabela 4. Somente a variável de ADM de flexão do joelho apresentou menor assimetria do grupo ipsilateral em relação ao grupo contralateral.

De acordo com Shelbourne e $\mathrm{Klotz}^{71}$ e Johnson ${ }^{72}$, as pessoas possuem joelho simétricos, que são únicos individualmente. Quando ocorre uma lesão em um dos joelhos, ele é deixado de lado para as atividades normais, tais como andar, agachar, subir e descer escadas. O problema evolui para a perda de movimento e força no membro lesionado, gerando assimetria. Para o retorno às atividades esportivas, é necessário que, além da ausência de sinais inflamatórios, haja simetria de ADM e desempenho muscular entre os membros, que permitirão o restabelecimento da funcionalidade.

Tabela 4: Testes de comparação média entre os membros dos grupos contralateral e ipsilateral no período pós-operatório para os parâmetros objetivos. Brasília - DF, 2019

\begin{tabular}{|c|c|c|c|c|}
\hline \multicolumn{5}{|c|}{ CONTRALATERAL } \\
\hline PARÂMETROS & MEMBRO & MÉDIA & $\begin{array}{l}\text { DESVIO } \\
\text { PADRÃO }\end{array}$ & $\begin{array}{l}\text { DIFERENÇA } \\
\text { NUMÉRICA }\end{array}$ \\
\hline \multirow{2}{*}{ ADM hiperextensão } & Doador & 5,92 & 3,42 & \multirow{2}{*}{2,55} \\
\hline & Receptor & 3,37 & 3,50 & \\
\hline \multirow{2}{*}{ ADM flexão } & Doador & 145,74 & 4,90 & \multirow{2}{*}{3,19} \\
\hline & Receptor & 142,55 & 6,34 & \\
\hline \multirow{2}{*}{ KT-1000 } & Doador & 5,8 & 1,8 & \multirow{2}{*}{1,1} \\
\hline & Receptor & 6,9 & 1,7 & \\
\hline \multirow{2}{*}{ PT extensão } & Doador & 142,9 & 42,6 & \multirow{2}{*}{38,2} \\
\hline & Receptor & 181,1 & 68,2 & \\
\hline SLHT & Doador & 98,6 & 31,9 & 7,5 \\
\hline
\end{tabular}




\begin{tabular}{|c|c|c|c|c|}
\hline & Receptor & 91,1 & 33 & \\
\hline \multirow{2}{*}{ YBT Anterior } & Doador & 61,62 & 7,46 & \multirow{2}{*}{1,08} \\
\hline & Receptor & 62,70 & 6,18 & \\
\hline \multirow{2}{*}{ YBT Póstero-lateral } & Doador & 101,11 & 7,72 & \multirow{2}{*}{2,33} \\
\hline & Receptor & 103,44 & 8,93 & \\
\hline \multirow{2}{*}{ YBT Póstero-medial } & Doador & 95,25 & 8,77 & \multirow{2}{*}{0,04} \\
\hline & Receptor & 95,29 & 8,27 & \\
\hline \multicolumn{5}{|c|}{ IPSILATERAL } \\
\hline \multirow{2}{*}{ PARÂMETROS } & \multirow{2}{*}{ MEMBRO } & \multirow{2}{*}{ MÉDIA } & DESVIO & DIFERENÇA \\
\hline & & & PADRÃO & NUMÉRICA \\
\hline \multirow{2}{*}{ ADM hiperextensão } & Sadio & 5,22 & 3,96 & \multirow{2}{*}{1,63} \\
\hline & Operado & 3,59 & 3,76 & \\
\hline \multirow{2}{*}{ ADM flexão } & Sadio & 144,62 & 6,25 & \multirow{2}{*}{5,92} \\
\hline & Operado & 138,7 & 8,8 & \\
\hline \multirow{2}{*}{ KT-1000 } & Sadio & 4,5 & 1,6 & \multirow{2}{*}{2,2} \\
\hline & Operado & 6,7 & 1,8 & \\
\hline \multirow{2}{*}{ PT extensão } & Sadio & 224,5 & 39,1 & \multirow{2}{*}{110,2} \\
\hline & Operado & 114,3 & 30,5 & \\
\hline \multirow{2}{*}{ SLHT } & Sadio & 122,9 & 41,9 & \multirow{2}{*}{42,2} \\
\hline & Operado & 80,7 & 41,7 & \\
\hline \multirow{2}{*}{ YBT Anterior } & Sadio & 66,66 & 10,15 & \multirow{2}{*}{4,55} \\
\hline & Operado & 62,11 & 11,83 & \\
\hline \multirow{2}{*}{ YBT Póstero-lateral } & Sadio & 106,42 & 10,95 & \multirow{2}{*}{6,3} \\
\hline & Operado & 100,12 & 10,04 & \\
\hline \multirow{2}{*}{ YBT Póstero-medial } & Sadio & 96,16 & 12,57 & \multirow{2}{*}{5,81} \\
\hline & Operado & 90,35 & 12,91 & \\
\hline
\end{tabular}

Ao analisar a evolução dos membros receptor (grupo contralateral) e operado (grupo ipsilateral), nos períodos pré e pós-operatório, para os parâmetros objetivos de avaliação, constatou-se que ambas as técnicas cirúrgicas apresentaram variação percentual negativa em todas as variáveis (Tabela 5). O pico de torque extensor do 
joelho foi a variável com maior diferença de variação percentual entre os membros de cada grupo, tendo o pico extensor do grupo ipsilateral sofrido redução média de $36,88 \%$ após a cirurgia, enquanto o pico extensor do grupo contralateral reduziu em média 10,25\%, como demonstra a tabela 5 .

Tabela 5: Comparação da evolução entre os membros receptor (contralateral) e operado (ipsilateral) nos períodos pré e pós-operatório para os parâmetros objetivos. Brasília DF, 2019

\begin{tabular}{|c|c|c|c|}
\hline PARÂMETROS & PRÉ OPERATÓRIO & PÓS OPERATÓRIO & \multirow{2}{*}{$\begin{array}{c}\text { VARIAÇÃO } \\
\text { PERCENTUAL }\end{array}$} \\
\hline & \multicolumn{2}{|c|}{ RECEPTOR - CONTRALATERAL } & \\
\hline ADM hiperextensão & 6,33 & 3,37 & $-46,76 \%$ \\
\hline ADM flexão & 144,55 & 142,55 & $-1,38 \%$ \\
\hline KT-1000 & 8,1 & 6,9 & $-14,81 \%$ \\
\hline PT extensão & 201,8 & 181,1 & $-10,25 \%$ \\
\hline \multicolumn{4}{|c|}{ OPERADO - IPSILATERAL } \\
\hline ADM hiperextensão & 6,92 & 3,59 & $-48,12 \%$ \\
\hline ADM flexão & 143,18 & 138,7 & $-3,12 \%$ \\
\hline KT-1000 & 8,6 & 6,7 & $-22,09 \%$ \\
\hline PT extensão & 181,1 & 114,3 & $-36,88 \%$ \\
\hline
\end{tabular}

Comparando as evoluções dos membros doador (grupo contralateral) e sadio (grupo ipsilateral) desde o pré-operatório ao 4으 mês pós cirúrgico, percebeu-se que o membro doador do grupo contralateral foi o que sofreu mais reduções de desempenho em cada parâmetro avaliado, destacando-se a média numérica do Single Leg Hop Test ($20,54 \%)$ e o pico extensor do joelho, que sofreu o maior déficit entre entre todas as variáveis (-39,39\%) (Tabela 6).

A literatura acerca da RLCA contralateral e ipsilateral é clara quanto aos métodos de tratamento, porém não são encontrados novos estudos comparando a evolução do ganho de força. 
No Brasil, os primeiros trabalhos relacionados ao procedimento foram feitos por Oliveira et al. ${ }^{73}$ e Lobo et al. ${ }^{74}$. O primeiro apresentou os resultados da recuperação em curto prazo de uma atleta profissional de voleibol que, com três semanas de pósoperatório, apresentava ADM completa de flexão, hiperextensão e independência funcional para todas as suas AVD's. No trabalho de Lobo et al. ${ }^{74}$, mais amplo, foram apresentados os resultados de 2 anos de acompanhamento pós-cirurgia de 256 pacientes, com a faixa etária compreendida entre 13-70 anos, sendo 160 do gênero masculino e 27 do feminino. Eles foram avaliados e classificados como em condições adequadas quanto à estabilidade ligamentar objetiva $\left(\mathrm{KT}-1000^{\mathrm{Tm}}\right)$, amplitude de movimento (goniometria), trofismo (perimetria), nível de satisfação e tempo de retorno às atividades (registrado em prontuário).

Apesar de ambos os trabalhos descreverem pacientes que exibiram 0 restabelecimento de variados parâmetros para alta do tratamento, o desempenho muscular não foi verificado, limitando assim a obtenção de novas informações sobre a condição dos pacientes no momento da alta. Somente os trabalhos de Leal et al. ${ }^{75} \mathrm{e}$ Oliveira et al. ${ }^{76}$ trouxeram os primeiros resultados nesse sentido.

No trabalho de Leal et al. ${ }^{75}$ foram avaliados de forma transversal 22 indivíduos na faixa etária compreendida entre 18 e 48 anos, sendo 19 (86\%) do gênero masculino e $3(14 \%)$ do gênero feminino, com média de idade de 34,55 $\pm 8,5$ anos. Todos(as) haviam sido submetidos à RLCA com enxerto do ligamento da patela contralateral pelo mesmo cirurgião e a um programa comum de reabilitação, se encontrando no período de 3 a 10 anos após o procedimento. Os resultados demonstraram assimetria significativa entre os membros doador e receptor para o Single Leg Hop Test, relação I/Q e pico de torque de extensão à 60\%/s e 180\%/s.

$\mathrm{O}$ trabalho de Oliveira et al. ${ }^{76}$ era semelhante, porém com o objetivo avaliar a condição clínica dos pacientes no momento de alta (curto prazo). Ao total participaram 23 indivíduos, praticantes de esportes em nível recreacional, sendo 20 do gênero masculino e 3 do gênero feminino, com a média de idade de 25,61 anos. 0 tempo médio transcorrido a cirurgia e o momento da avaliação foi de 5,04 meses. Os pacientes encontravam-se recuperados do ponto de vista funcional (testes físicos e resultados dos questionários), porém a avaliação isocinética demonstrou a presença de diferenças 
significativas no desempenho muscular entre os membros, no qual o doador se mostrava deficiente.

Pensando no retorno ao esporte, Petersen et al. ${ }^{77}$ realizou uma revisão sistemática sobre déficits musculares após a RLCA. 45 estudos, com follow up mínimo de 24 meses, foram selecionados. A maioria das investigações demonstraram desequilíbrios musculares entre os membros receptores de enxerto e membros contralaterais. Déficits extensores do joelho estão associados ao enxerto do tendão patelar.

Tabela 6: Comparação da evolução entre os membros doador (contralateral) e sadio (ipsilateral) nos períodos pré e pós-operatório para os parâmetros objetivos. Brasília DF, 2019

\begin{tabular}{|c|c|c|c|}
\hline PARÂMETROS & PRÉ OPERATÓRIO & PÓS OPERATÓRIO & \multirow{2}{*}{$\begin{array}{l}\text { VARIAÇÃO } \\
\text { PERCENTUAL }\end{array}$} \\
\hline & \multicolumn{2}{|c|}{ DOADOR - CONTRALATERAL } & \\
\hline ADM hiperextensão & 7,25 & 5,92 & $-18,34 \%$ \\
\hline ADM flexão & 148,96 & 145,74 & $-2,16 \%$ \\
\hline KT-1000 & 4,4 & 5,8 & $31,81 \%$ \\
\hline PT extensão & 235,8 & 142,9 & $-39,39 \%$ \\
\hline SLHT & 124,1 & 98,6 & $-20,54 \%$ \\
\hline YBT Anterior & 64,40 & 61,62 & $-4,31 \%$ \\
\hline YBT Póstero-lateral & 94,55 & 101,11 & $6,93 \%$ \\
\hline YBT Póstero-medial & 101,81 & 95,25 & $-6,44 \%$ \\
\hline \multicolumn{4}{|c|}{ SADIO - IPSILATERAL } \\
\hline ADM hiperextensão & 7,48 & 5,22 & $-30,20 \%$ \\
\hline ADM flexão & 147,55 & 144,62 & $-1,98 \%$ \\
\hline KT-1000 & 3,9 & 4,5 & $15,38 \%$ \\
\hline PT extensão & 220 & 224,5 & $2,04 \%$ \\
\hline SLHT & 127,6 & 122,9 & $-3,68 \%$ \\
\hline YBT Anterior & 63,85 & 66,66 & $4,4 \%$ \\
\hline YBT Póstero-lateral & 89,85 & 106,42 & $18,44 \%$ \\
\hline
\end{tabular}




\begin{tabular}{|l|l|l|l|}
\hline YBT Póstero-medial & 99,33 & 96,16 & $-\mathbf{3 , 1 9 \%}$ \\
\hline
\end{tabular}

Quanto à progressão dos parâmetros subjetivos entre os grupos ipsilateral e contralateral, nota-se que o grupo ipsilateral apresentou melhor evolução para a EAVD e o Questionário de Lysholm do que o grupo contralateral, todavia, a percepção de dor nos joelhos, pela Escala Visual Analógica de dor, foi maior no grupo ipsilateral quando comparado ao grupo contralateral (Tabela 7).

Tabela 7: Comparação entre os momentos pré e pós-operatório no interior dos grupos para os parâmetros subjetivos: Escala Visual Analógica de Dor (EVA), Escala de Atividades de Vida Diária (EAVD) e Questionário Lysholm. Brasília - DF, 2019

\begin{tabular}{|c|c|c|c|}
\hline PARÂMETROS & PRÉ OPERATÓRIO & PÓS OPERATÓRIO & \multirow{2}{*}{$\begin{array}{c}\text { VARIAÇÃO } \\
\text { PERCENTUAL }\end{array}$} \\
\hline \multicolumn{3}{|c|}{ CONTRALATERAL } & $\mathbf{6 6 , 2 5 \%}$ \\
\hline EVA & 0,8 & 1,33 & $\mathbf{9 , 8 \%}$ \\
\hline EAVD & 75,85 & 83,29 & $\mathbf{6 , 4 3 \%}$ \\
\hline Lysholm & 78,33 & 83,37 & $\mathbf{7 2 , 0 3 \%}$ \\
\hline \multicolumn{4}{|c|}{ IPSILATERAL } \\
\hline EVA & 1,18 & 2,03 & $\mathbf{1 0 , 4 7 \%}$ \\
\hline EAVD & 70,37 & 77,74 & $\mathbf{1 0 , 0 8 \%}$ \\
\hline
\end{tabular}

\section{CONSIDERAÇÕES FINAIS}

Diante do exposto, conclui-se que os pacientes que firam operados utilizando o autoenxerto patelar contralateral sofreram mais com redução das suas capacidades em ambos os membros, porém apresentavam maior simetria entre os membros. Por outro lado, pacientes submetidos à RLCA com o autoenxerto ipsilateral apresentaram 
assimetrias importantes, embora tenham atingido melhores resultados para EAVD e Questionário Lysholm.

É bem aceito entre os profissionais pacientes e atletas, que a medida do sucesso do tratamento do LCA é o retorno ao esporte, atividades físicas e AVD's no mesmo nível que anteriormente à lesão. Nesse sentido, encontrar uma maneira mais efetiva de se obter a simetria entre os membros durante o processo de reabilitação, fator preponderante para um retorno seguro, torna-se não apenas relevante, mas uma necessidade para os profissionais e pacientes.

Os resultados desta pesquisa contribuem na busca por novos caminhos para o tratamento dos pacientes com lesões do LCA, no entanto, novos estudos devem ser desenvolvidos para que se potencializem os benefícios do processo cirúrgico e da reabilitação deste grupo. Em síntese, apesar do tratamento curativo e mesmo após este, sabe-se que existe um longo caminho para prevenir novas lesões, complicações pós cirúrgicas e estabelecer critérios mais precisos de tratamento dos pacientes.

\section{REFERÊNCIAS BIBLIOGRÁFICAS}

1. JENSEN, Jack E. et al. Reconstruction procedures for anterior cruciate ligament insufficiency: a computer analysis of clinical results. The American journal of sports medicine, v. 11, n. 4, p. 240-248, 1983.

2. MALL, Nathan A. et al. Incidence and trends of anterior cruciate ligament reconstruction in the United States. The American journal of sports medicine, $v$. 42, n. 10, p. 2363-2370, 2014.

3. LOPES, Thiago Jambo Alves; SIMIC, Milena; PAPPAS, Evangelos. Epidemiology of anterior cruciate ligament reconstruction in Brazil's public health system. Revista Brasileira de Medicina do Esporte, v. 22, n. 4, p. 297-301, 2016.

4. ARNOLD, Todd; SHELBOURNE, K. Donald. A perioperative rehabilitation program for anterior cruciate ligament surgery. The Physician and sportsmedicine, v. 28, n. 1, p. 31-44, 2000. 
5. FU, Freddie H. et al. Primary anatomic double-bundle anterior cruciate ligament reconstruction: a preliminary 2-year prospective study. The American journal of sports medicine, v. 36, n. 7, p. 1263-1274, 2008.

6. SHELBOURNE, K. Donald; URCH, Scott E. Primary anterior cruciate ligament reconstruction using the contralateral autogenous patellar tendon. The American journal of sports medicine, v. 28, n. 5, p. 651-658, 2000.

7. ANDREWS, James R. Reabilitação física das lesões desportivas. Guanabara Koogan, 2000.

8. AMATUZZI, Marco Martins. Joelho: Articulação central dos membros inferiores. Editora Roca, 2004.

9. NIXON, Rick G. et al. Reconstitution of the patellar tendon donor site after graft harvest. Clinical orthopaedics and related research, n. 317, p. 162-171, 1995.

10. RUBINSTEIN JR, Richard A. et al. Isolated autogenous bone-patellar tendon-bone graft site morbidity. The American journal of sports medicine, v. 22, n. 3, p. 324327, 1994.

11. SHELBOURNE, K. Donald; DAVIS, Thorp J. Evaluation of knee stability before and after participation in a functional sports agility program during rehabilitation after anterior cruciate ligament reconstruction. The American journal of sports medicine, v. 27, n. 2, p. 156-161, 1999.

12. PACCINI LUSTOSA, Lygia; TEIXEIRA FONSECA, Sérgio; PERCOPE DE ANDRADE, Marco Antônio. Reconstrução do ligamento cruzado anterior: impacto do desempenho muscular e funcional no retorno ao mesmo nível de atividade prélesão. Acta Ortopédica Brasileira, v. 15, n. 5, 2007.

13. DIO, D. I.; LIBERATO, John Alphonse. Tratado de Anatomia Sistêmica Aplicada. São Paulo: Atheneu, 2002.

14. FLANDRY, Fred; HOMMEL, Gabriel. Normal anatomy and biomechanics of the knee. Sports medicine and arthroscopy review, v. 19, n. 2, p. 82-92, 2011.

15. MOREIRA, D.; GODOY, J. R.; SILVA JR, W. Anatomia e cinesiologia clínica do aparelho do movimento. São Paulo: Thesaurus, 2004.

16. ORTOPÉDICA, Dutton M. Fisioterapia. exame, avaliação e intervenção. Porto Alegre: Artmed, 2006.

17. FRANK, Cyril B.; JACKSON, Douglas W. Current concepts review-the science of 
reconstruction of the anterior cruciate ligament. JBJS, v. 79, n. 10, p. 1556-76, 1997.

18. SHELBOURNE, K. Donald; Bavornrat; GRAY, Tinker. Primary anterior cruciate ligament reconstruction using contralateral patellar tendon autograft. Clinics in sports medicine, v. 26, n. 4, p. 549-565, 2007.

19. HUSTON, Laura J.; WOJTYS, Edward M. Neuromuscular performance characteristics in elite female athletes. The American journal of sports medicine, v. 24, n. 4, p. 427-436, 1996.

20. GRIFFIN, Letha Y. et al. Noncontact anterior cruciate ligament injuries: risk factors and prevention strategies. JAAOS-Journal of the American Academy of Orthopaedic Surgeons, v. 8, n. 3, p. 141-150, 2000.

21. MULLIGAN, Edward P. et al. The reliability and diagnostic accuracy of assessing the translation endpoint during the lachman test. International journal of sports physical therapy, v. 10, n. 1, p. 52, 2015.

22. GOODWILLIE, Andrew D. et al. The effect of postoperative KT-1000 arthrometer score on long-term outcome after anterior cruciate ligament reconstruction. The American journal of sports medicine, v. 45, n. 7, p. 1522-1528, 2017.

23. BACH, Bernard R. et al. Arthroscopically assisted anterior cruciate ligament reconstruction using patellar tendon autograft. The American journal of sports medicine, v. 26, n. 1, p. 20-29, 1998.

24. KLINE, Paul W. et al. Impaired quadriceps rate of torque development and knee mechanics after anterior cruciate ligament reconstruction with patellar tendon autograft. The American journal of sports medicine, v. 43, n. 10, p. 2553-2558, 2015.

25. NOMURA, Y.; KURAMOCHI, R.; FUKUBAYASHI, T. Evaluation of hamstring muscle strength and morphology after anterior cruciate ligament reconstruction. Scandinavian journal of medicine \& science in sports, v. $25, \mathrm{n}$. 3, p. 301-307, 2015.

26. LEPORACE, Gustavo; METSAVAHT, Leonardo; DE MELLO SPOSITO, Maria Matilde. Importância do treinamento da propriocepção e do controle motor na reabilitação após lesões músculo-esqueléticas. Acta fisiátrica, v. 16, n. 3, p. 126131, 2016. 
27. SHELBOURNE, Donald K.; BECK, Matthew B.; GRAY, Tinker. evaluation of Donor Site Strength and Subjective Results: anterior Cruciate Ligament Reconstruction With Contralateral Autogenous Patellar Tendon Graft. American Journal of Sports Medicine, v. 43, n. 3, p. 648-653, 2015.

28. FU, Freddie H.; HARNER, Christopher D. (Ed.). Knee surgery. Williams \& Wilkins, 1994.

29. SMITH, Craig A.; CHIMERA, Nicole J.; WARREN, Meghan. Association of y balance test reach asymmetry and injury in division I athletes. Medicine and science in sports and exercise, v. 47, n. 1, p. 136-141, 2015.

30. GONELL, Alfonso Calvo; ROMERO, José Aurelio Pina; SOLER, Loreto Maciá. Relationship between the $Y$ balance test scores and soft tissue injury incidence in a soccer team. International journal of sports physical therapy, v. 10, n. 7, p. 955, 2015.

31. WELLSANDT, Elizabeth; FAILLA, Mathew J.; SNYDER-MACKLER, Lynn. Limb symmetry indexes can overestimate knee function after anterior cruciate ligament injury. journal of orthopaedic \& sports physical therapy, v. 47, n. 5, p. 334-338, 2017.

32. BENJAMINSE, Anne; HOLDEN, Sinead; MYER, Gregory D. ACL rupture is a single leg injury but a double leg problem: too much focus on 'symmetry'alone and that's not enough!. Br J Sports Med, v. 52, n. 16, p. 1029-1030, 2018.

33. BRIGGS, Karen K. et al. The reliability, validity, and responsiveness of the Lysholm score and Tegner activity scale for anterior cruciate ligament injuries of the knee: 25 years later. The American journal of sports medicine, v. 37, n. 5, p. 890-897, 2009.

34. COLLINS, Natalie J. et al. Measures of knee function: International Knee Documentation Committee (IKDC) Subjective Knee Evaluation Form, Knee Injury and Osteoarthritis Outcome Score (KOOS), Knee Injury and Osteoarthritis Outcome Score Physical Function Short Form (KOOS-PS), Knee Outcome Survey Activities of Daily Living Scale (KOS-ADL), Lysholm Knee Scoring Scale, Oxford Knee Score (OKS), Western Ontario and McMaster Universities Osteoarthritis Index (WOMAC), Activity Rating Scale (ARS), and Tegner Activity Score (TAS). Arthritis care \& research, v. 63, n. S11, p. S208-S228, 2011. 
35. LYSHOLM, Jack; GILLQUIST, Jan. Evaluation of knee ligament surgery results with special emphasis on use of a scoring scale. The American journal of sports medicine, v. 10, n. 3, p. 150-154, 1982.

36. KOSE, Ozkan et al. A comparison of telephone interview versus on-site completion of Lysholm knee score in patients who underwent arthroscopic $\mathrm{ACL}$ reconstruction: are the results equivalent?. European Journal of Orthopaedic Surgery \& Traumatology, v. 25, n. 6, p. 1069-1072, 2015.

37. RA, Ho Jong et al. Comparison of the ceiling effect in the Lysholm score and the IKDC subjective score for assessing functional outcome after ACL reconstruction. The Knee, v. 21, n. 5, p. 906-910, 2014.

38. PECCIN, Maria Stella; CICONELLI, Rozana; COHEN, Moisés. Questionário específico para sintomas do joelho" Lysholm Knee Scoring Scale"-tradução e validação para a língua portuguesa. Acta Ortopédica Brasileira, v. 14, n. 5, p. 268-272, 2006.

39. SZCZEPANIK, Magdalena et al. Polish Cross-Cultural Adaptation and Validation of the Knee Outcome Survey Activities of Daily Living Scale (KOS-ADLS) in Patients Undergoing Total Knee Arthroplasty. Medical science monitor: international medical journal of experimental and clinical research, v. 24, p. 5309, 2018.

40. GONÇALVES, Rui Soles; CABRI, Jan; PINHEIRO, João Páscoa. Cross-cultural adaptation and validation of the Portuguese version of the Knee Outcome Survey-Activities of Daily Living Scale (KOS-ADLS). Clinical rheumatology, v. 27, n. 11, p. 1445-1449, 2008.

41. MARTINEZ, José Eduardo; GRASSI, Daphine Centola; MARQUES, Laura Gasbarro. Análise da aplicabilidade de três instrumentos de avaliação de dor em distintas unidades de atendimento: ambulatório, enfermaria e urgência. Rev Bras Reumatol, v. 51, n. 4, p. 299-308, 2011.

42. SILVA, Fabiana Coêlho da; DELIBERATO, Paulo César Porto. Análise das escalas de dor: revisão de literatura. 2009.

43. DAVIES, George J.; RIEMANN, Bryan; ELLENBECKER, Todd. Role of Isokinetic Testing and Training After ACL Injury and Reconstruction. In: ACL Injuries in the Female Athlete. Springer, Berlin, Heidelberg, 2018. p. 567-588.

44. TERRERI, Antonio Sérgio AP; GREVE, Júlia; AMATUZZI, Marco M. Avaliaçåo 
isocinética no joelho do atleta. Rev. Bras. med. esporte, v. 7, n. 5, p. 170-174, 2001.

45. MACHADO, Felipe et al. Knee isokinetic performance following anterior cruciate ligament reconstruction: patellar tendon versus hamstrings graft. The Physician and sportsmedicine, v. 46, n. 1, p. 30-35, 2018.

46. BERNARD, P. L. et al. Influence of recovery time on strength during a testing protocol of knee. Journal de Traumatologie du Sport, v. 33, n. 3, p. 161-166, 2016.

47. AQUINO, C. F. et al. A ultilização da dinamometria isocinética nas ciências do esporte e reabilitação. Revista brasileira de Ciência e Movimento, v. 15, n. 1, p. 93-100, 2008.

48. UNDHEIM, Marit Baste et al. Isokinetic muscle strength and readiness to return to sport following anterior cruciate ligament reconstruction: is there an association? A systematic review and a protocol recommendation. Br J Sports Med, v. 49, n. 20, p. 1305-1310, 2015.

49. CARVALHO, Paulo; PUGA, Nelson. A avaliação isocinética-joelho. Revista de Medicina Desportiva in forma, v. 1, n. 4, p. 26-28, 2010.

50. PATEL, Rohita R. et al. Comparison of clinical and dynamic knee function in patients with anterior cruciate ligament deficiency. The American journal of sports medicine, v. 31, n. 1, p. 68-74, 2003.

51. KARANIKAS, K.; ARAMPATZIS, A.; BRUGgEMANN, G. P. Motor task and muscle strength followed different adaptation patterns after anterior cruciate ligament reconstruction. Eur J Phys Rehabil Med, v. 45, n. 1, p. 37-45, 2009.

52. LAUDNER, Kevin et al. Relationship between isokinetic knee strength and jump characteristics following anterior cruciate ligament reconstruction. International journal of sports physical therapy, v. 10, n. 3, p. 272, 2015.

53. ARDERN, C. L. et al. Comparison of patient-reported outcomes among those who chose $A C L$ reconstruction or non-surgical treatment. Scandinavian journal of medicine \& science in sports, v. 27, n. 5, p. 535-544, 2017.

54. AHLDÉN, M. et al. Individualized therapy is important in anterior cruciate ligament injuries. Lakartidningen, v. 111, n. 36, p. 1440-1443, 2014. 
55. OLIESTAD, B. E. et al. Knee osteoarthritis after anterior cruciate ligament injury. Am J Sports Med, v. 37, n. 7, p. 1434-1443, 2009.

56. ARDERN, Clare L. et al. Fifty-five per cent return to competitive sport following anterior cruciate ligament reconstruction surgery: an updated systematic review and meta-analysis including aspects of physical functioning and contextual factors. Br J Sports Med, v. 48, n. 21, p. 1543-1552, 2014.

57. NOYES, FRANK R. et al. The symptomatic anterior cruciate-deficient knee. Part I: the long-term functional disability in athletically active individuals. JBJS, v. 65, n. 2, p. 154-162, 1983.

58. BEYNNON, Bruce D. et al. The effect of estradiol and progesterone on knee and ankle joint laxity. The American journal of sports medicine, v. 33, n. 9, p. 12981304, 2005.

59. ALSHEWAIER, Shady; YEOWELL, Gillian; FATOYE, Francis. The effectiveness of pre-operative exercise physiotherapy rehabilitation on the outcomes of treatment following anterior cruciate ligament injury: A systematic review. Clinical rehabilitation, v. 31, n. 1, p. 34-44, 2017.

60. FROBELL, Richard B. et al. Treatment for acute anterior cruciate ligament tear: five year outcome of randomised trial. Bmj, v. 346, p. f232, 2013.

61. LEPLEY, Lindsey K.; PALMIERI-SMITH, Riann M. Pre-operative quadriceps activation is related to post-operative activation, not strength, in patients postACL reconstruction. Knee Surgery, Sports Traumatology, Arthroscopy, v. 24, n. 1, p. 236-246, 2016.

62. VINAGRE, Gustavo; SARAIVA, João. Anterior Cruciate Ligament Reconstruction Graft Options. Orthopaedic Journal of Sports Medicine, v. 6, n. 6_suppl3, p. 2325967118S00048, 2018.

63. SHELBOURNE, K. Donald; NITZ, Paul. Accelerated rehabilitation after anterior cruciate ligament reconstruction. The American journal of sports medicine, v. 18, n. 3, p. 292-299, 1990.

64. SPENCER, Jennifer D.; HAYES, K. C.; ALEXANDER, Ian J. Knee joint effusion and quadriceps reflex inhibition in man. Archives of physical medicine and rehabilitation, v. 65 , n. 4, p. 171-177, 1984.

65. CZUPPON, Sylvia et al. Variables associated with return to sport following 
anterior cruciate ligament reconstruction: a systematic review. Br J Sports Med, v. 48, n. 5 , p. 356-364, 2014.

66. RELPH, Nicola; HERRINGTON, Lee; TYSON, Sarah. The effects of ACL injury on knee proprioception: a meta-analysis. Physiotherapy, v. 100, n. 3, p. 187-195, 2014.

67. PRODOMOS, Chadwick C. et al. A meta-analysis of stability after anterior cruciate ligament reconstruction as a function of hamstring versus patellar tendon graft and fixation type. Arthroscopy: The Journal of Arthroscopic \& Related Surgery, v. 21, n. 10, p. 1202. e1-1202. e9, 2005.

68. LARSON, Robert L.; TAILON, M. Anterior Cruciate Ligament Insufficiency: Principles of Treatment. The Journal of the American Academy of Orthopaedic Surgeons, v. 2, n. 1, p. 26-35, 1994.

69. SUTTON, Karen M.; BULLOCK, James Montgomery. Anterior cruciate ligament rupture: differences between males and females. JAAOS-Journal of the American Academy of Orthopaedic Surgeons, v. 21, n. 1, p. 41-50, 2013.

70. FERRETTI, Andrea et al. Prevalence and classification of injuries of anterolateral complex in acute anterior cruciate ligament tears. Arthroscopy: The Journal of Arthroscopic \& Related Surgery, v. 33, n. 1, p. 147-154, 2017.

71. SHELBOURNE, K. Donald; KLOTZ, Christine. What I have learned about the ACL: utilizing a progressive rehabilitation scheme to achieve total knee symmetry after anterior cruciate ligament reconstruction. Journal of Orthopaedic Science, v. 11, n. 3, p. 318, 2006.

72. JOHNSON, Dave. Controlling anterior shear during isokinetic knee extension exercise. Journal of Orthopaedic \& Sports Physical Therapy, v. 4, n. 1, p. 23-31, 1982.

73. OLIVEIRA, Marcio; Godoy, JRP; Valduga, R. et al. Programa de reabilitação de ambos os joelhos após a cirurgia primária de reconstrução do LCA utilizando enxerto autógeno de ligamento patelar contralateral. In: 11 Congresso Brasileiro de Artroscopia e 12 Congresso Brasileiro de Artroscopia. Salvador. Anais, 2006.

74. LOBO, Paulo, LOBO R, Neto AR. et al. Resultados clínico/funcionais pósreconstrução primária do ligamento cruzado anterior com tendão patelar 
contralateral. Seguimento de 02 anos. In: 11으 Congresso Brasileiro de Artroscopia e 12 Congresso Brasileiro de Artroscopia. Salvador. Anais, 2006.

75. LEAL, Tatiana Sihler et al. Avaliação dos graus de hiperextensão do joelho em praticantes de atividade física. Universitas: Ciências da Saúde, v. 9, n. 2, p. 1934, 2011.

76. DE PAULA E OLIVEIRA, Márcio et al. Resultados em curto prazo de reabilitação após cirurgia de reconstrução de ligamento cruzado anterior utilizando-se enxerto de tendão patelar contralateral. Universitas. Ciencias da Saude, v. 12, n. 1, 2014.

77. PETERSEN, Wolf et al. Return to play following $A C L$ reconstruction: a systematic review about strength deficits. Archives of orthopaedic and trauma surgery, v. 134, n. 10, p. 1417-1428, 2014.

\section{ANEXOS}

\section{ANEXO I - Termo de Consentimento Livre e Esclarecido (TCLE)}

\section{Termo de Consentimento Livre e Esclarecido - TCLE}

Comparação pós-operatória dos resultados clinicofuncionais dos pacientes submetidos a reconstrução cirúrgica do LCA do joelho com utilização de auto-enxerto patelar ipsilateral ou contralateral

Instituição dos pesquisadores: Hospital Ortopédico e Medicina Especializada Pesquisador responsável: Márcio de Paula e Oliveira Pesquisadores assistentes: José Humberto de Souza Borges; Darlan Malba Dias; Paulo Lobo Junior; Anderson Freitas; Pedro Nunes Silva

Você está sendo convidado(a) a participar do projeto de pesquisa acima citado. O texto abaixo apresenta todas as informações necessárias sobre o que estamos fazendo. Sua colaboração neste estudo será de muita importância para nós, mas se desistir a qualquer momento, isso não 
Ihe causará prejuízo.

O nome deste documento é Termo de Consentimento Livre e Esclarecido (TCLE).

Antes de decidir se deseja participar (de livre e espontânea vontade) você deverá ler e compreender todo o conteúdo. Ao final, caso decida participar, você será solicitado a assiná-lo e receberá uma cópia do mesmo.

Antes de assinar, faça perguntas sobre tudo o que não tiver entendido bem. A equipe deste estudo responderá às suas perguntas a qualquer momento (antes, durante e após o estudo).

\section{Natureza e objetivos do estudo}

- O objetivo específico deste estudo é comparar duas diferentes técnicas na reconstrução do ligmanto cruzado anterior do joelho obtendo dados clínicos e funcionais afim de desenvolvimento das técnicas para melhores resultados nos pacientes que necessitarão deste procedimento.

- Você está sendo convidado a participar exatamente por ter sido ou será submetido a cirurgia do joelho com uma das técnicas alvo deste estudo, podendo colaborar para o desenvolvimento científico.

\section{Procedimentos do estudo}

- Sua participação consiste em submeter-se a uma avaliação clinicofuncional pré e/ou após a reconstrução do ligamento cruzado anterior do joelho, além de autorizar a revisão do seu prontuário médico para coleta de dados para o estudo.

- Não haverá nenhuma outra forma de envolvimento ou comprometimento neste estudo. • A pesquisa será realizada no Hospital HOME e Clínicas de reabilitação associadas.

\section{Riscos e benefícios}

- Este estudo possui riscos mínimos já que se trata apenas de coleta de dados do prontuário e avaliação clínicafuncional do paciente.

- Medidas preventivas como acompanhamento médico e fisioterapêutico serão tomadas durante a avaliação para minimizar qualquer risco ou incômodo.

- Caso esse procedimento possa gerar algum tipo de constrangimento, você não precisa realizálo.

- Com sua participação nesta pesquisa você poderá ficar ciente sobre como está sua recuperação além de contribuir para maior conhecimento sobre os resultados clinicos funcionais dos pacientes operados por estas técnicas.

\section{Participação, recusa e direito de se retirar do estudo}

- Sua participação é voluntária. Você não terá nenhum prejuízo se não quiser participar

- Você poderá se retirar desta pesquisa a qualquer momento, bastando para isso entrar em contato com um dos pesquisadores responsáveis. 
- Conforme previsto pelas normas brasileiras de pesquisa com a participação de seres humanos, você não receberá nenhum tipo de compensação financeira pela sua participação neste estudo.

\section{Confidencialidade}

- Seus dados serão manuseados somente pelos pesquisadores e não será permitido o acesso a outras pessoas.

- Os dados e instrumentos utilizados (por exemplo, fitas, entrevistas, questionários) ficarão guardados sob a responsabilidade de Márcio de Paula e Oliveira com a garantia de manutenção do sigilo e confidencialidade, e arquivados por um período de 5 anos; após esse tempo serão destruídos.

- Os resultados deste trabalho poderão ser apresentados em encontros ou revistas científicas. Entretanto, ele mostrará apenas os resultados obtidos como um todo, sem revelar seu nome, instituição a qual pertence ou qualquer informação que esteja relacionada com sua privacidade.

Se houver alguma consideração ou dúvida referente aos aspectos éticos da pesquisa, entre em contato com o Comitê de Ética em Pesquisa do Centro Universitário de Brasília - CEP/UniCEUB, que aprovou esta pesquisa, pelo telefone 3966.1511 ou pelo e-mail cep.uniceub@uniceub.br. Também entre em contato para informar ocorrências irregulares ou danosas durante a sua participação no estudo.

$\mathrm{Eu}$, RG após receber a explicação completa dos objetivos do estudo e dos procedimentos envolvidos nesta pesquisa concordo voluntariamente em fazer parte deste estudo.

Este Termo de Consentimento encontra-se impresso em duas vias, sendo que uma cópia será arquivada pelo pesquisador responsável, e a outra será fornecida ao senhor(a).

Brasília, de de 
Pesquisador assistente: Darlan Malba Dias, 61996771987 / darlanmalba@hotmail.com

Endereço do responsável pela pesquisa:

Instituição: Hospital Ortopédico e Medicina Especializa (HOME)

Endereço: SHCS; CONJUNTO C

Bairro: ASA SUL / 613 CEP: 70200730 Cidade: Brasília -DF

Telefones p/contato: 6138782878

ANEXO II - Ficha de avaliação clínica e funcional

\section{GRUPO DE JOELHO / IPE-HOME - FICHA DE AVALIAÇÃO TÉCNICA CIRÚRGICA:}

DATA: $I^{\prime}$

\section{IDENTIFICAÇÃO}

Nome:

E-mail:

Telefone(s):

Gênero: M( ) F ( ) Idade: Data de nascimento: I

Profissão / ocupação / esporte:

Posição / graduação:

Dominância:

Peso e estatura: I

Diagnóstico: 
Queixa principal:

História médica atual:

Observações (PA/FC):

Data da lesão: 1 Data da cirurgia:

I

Membro lesionado:

Membro doador: Membro receptor:

Tempo de retorno às atividades de vida diária após a cirurgia (meses):

Tempo de retorno à prática esportiva (s/ competições) após a cirurgia (meses):

Tempo de retorno à prática esportiva (c/ competições) após a cirurgia (meses): 


\section{INSPEÇÃO, PALPAÇÃO E AVALIAÇÃO DA DOR}

( ) Edema

MID ( ) Leve ( ) Moderado ( ) Grave MIE ( ) Leve ( ) Moderado ( ) Grave

( ) Alteração do trofismo:

MID ( ) Leve ( ) Moderado ( ) Grave MIE ( ) Leve ( ) Moderado ( ) Grave

( ) Cicatriz:

( ) Alteração da temperatura local

MID ( ) Leve ( ) Moderado ( ) Grave

MIE ( ) Leve ( ) Moderado ( ) Grave

Termografia:

Membro lesionado: - Membro doador: Membro receptor: . Membro sadio:

( ) Deformidade:

( ) Dor:

- Local(is):

0

Nota: MID MIE

KT-1000:

MID:

MIE: 
3. AVALIAÇÃO DA AMPLITUDE DE MOVIMENTO E CIRCUNFERÊNCIA SEGMENTAR

AMPLITUDE DE MOVIMENTO PASSIVO DO JOELHO

\begin{tabular}{|c|c|c|c|}
\cline { 2 - 4 } \multicolumn{1}{c|}{} & A & B & C \\
\hline Direito & Hiperextensão & Quanto falta para Extensão & Flexão \\
\hline Esquerdo & $\circ$ & $\circ$ & $\circ$ \\
\hline
\end{tabular}

CIRCUNFERÊNCIA ARTICULAR E DA COXA EM RELAÇÃO À

LINHA DO JOELHO (cm)

\begin{tabular}{|c|c|c|c|c|}
\cline { 2 - 5 } \multicolumn{1}{c|}{} & L.A. & 10 & 20 & 30 \\
\hline MID & & & & \\
\hline MIE & & & & \\
\hline
\end{tabular}




\section{QUESTIONÁRIO DE LYSHOLM}

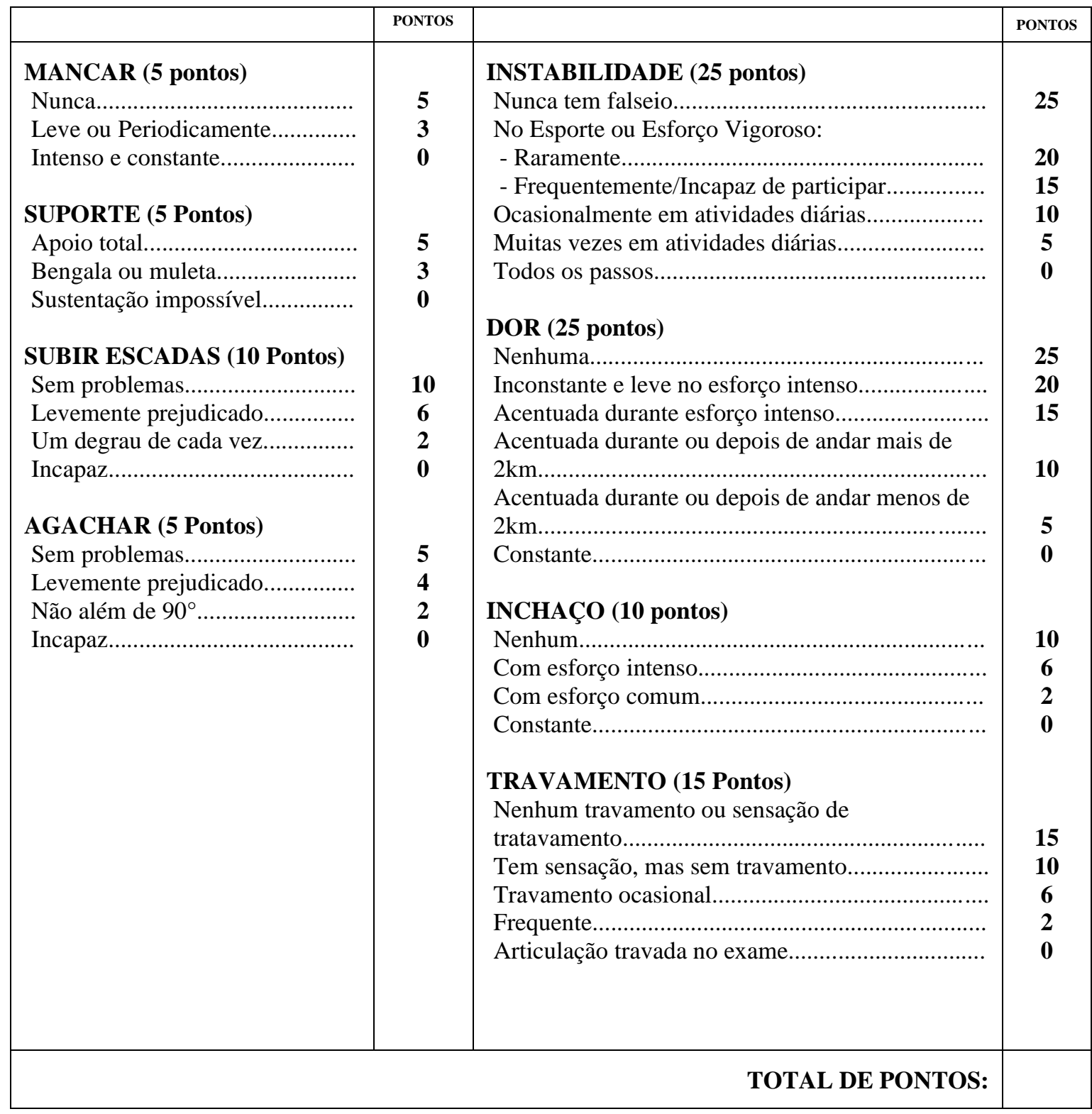

\section{CLASSIFICAÇÃO:}

(1) Excelente: 95-100

(2) Bom: 84-94

(3) Regular: 65-83

(4) Ruim: <64 


\section{ESCALA DE ATIVIDADES DE VIDA DIÁRIA (EAVD)}

\section{Instruções:}

O seguinte questionário foi formulado para que você possa demonstrar, os sintomas e limitações que apresenta no joelho enquanto você faz atividades de vida diária. Por favor, assinale uma única resposta, ou seja, a que melhor descreve esses sintomas e limitações nos últimos um ou dois dias (1 ou 2 dias). Para uma mesma pergunta, mais de uma resposta poderia servir, no entanto, assinale apenas aquela que melhor represente as dificuldades sentidas em sua atividade de vida diária.

\section{Sintomas}

O quanto cada um desses sintomas afeta sua atividade de vida diária? Marque uma resposta em cada linha.

\begin{tabular}{|c|c|c|c|c|c|c|}
\cline { 2 - 6 } \multicolumn{1}{c|}{} & $\begin{array}{c}\text { Eu não tenho } \\
\text { o sintoma }\end{array}$ & $\begin{array}{c}\text { Tenho o } \\
\text { sintoma } \\
\text { porém não } \\
\text { afeta as } \\
\text { minhas } \\
\text { atividades }\end{array}$ & $\begin{array}{c}\text { O sintoma } \\
\text { afeta } \\
\text { levemente as } \\
\text { minhas } \\
\text { atividades }\end{array}$ & $\begin{array}{c}\text { O sintoma afeta } \\
\text { moderadamente } \\
\text { as minhas } \\
\text { atividades }\end{array}$ & $\begin{array}{c}\text { O sintoma } \\
\text { afeta } \\
\text { extremamente } \\
\text { as minhas } \\
\text { atividades }\end{array}$ & $\begin{array}{c}\text { sinpede } \\
\text { impede } \\
\text { realizar } \\
\text { qualquer das } \\
\text { minhas } \\
\text { atividades } \\
\text { diárias }\end{array}$ \\
\hline Dor & & & & & & \\
\hline $\begin{array}{c}\text { Rigidez } \\
\text { Travamento }\end{array}$ & & & & & & \\
\hline Inchaço & & & & & & \\
\hline $\begin{array}{c}\text { Instabidade } \\
\text { (falta de } \\
\text { firmeza) }\end{array}$ & & & & & & \\
\hline Fraqueza & & & & & & \\
\hline Mancar & & & & & & \\
\hline
\end{tabular}

\section{Limitações Funcionais nas Atividades Diárias}

Como o seu joelho afeta sua capacidade de .... (marque uma resposta em cada linha):

\begin{tabular}{|c|l|c|l|l|l|l|}
\cline { 2 - 6 } \multicolumn{1}{c|}{} & Não dificulta & $\begin{array}{c}\text { Dificulta } \\
\text { minimamente }\end{array}$ & $\begin{array}{c}\text { Dificulta às } \\
\text { vezes }\end{array}$ & $\begin{array}{c}\text { Dificulta } \\
\text { moderadamente }\end{array}$ & $\begin{array}{c}\text { Dificulta } \\
\text { muito }\end{array}$ & $\begin{array}{c}\text { Impede de } \\
\text { realizar }\end{array}$ \\
\hline Andar? & & & & & & \\
\hline $\begin{array}{c}\text { Subir } \\
\text { escadas? }\end{array}$ & & & & & & \\
\hline $\begin{array}{c}\text { Descer } \\
\text { escadas? }\end{array}$ & & & & & & \\
\hline Ficar em pé? & & & & & & \\
\hline Ajoelhar? & & & & & & \\
\hline Agachar-se? & & & & & \\
\hline $\begin{array}{c}\text { Sentar com os } \\
\text { joelhos } \\
\text { dobrados a 90 } \\
\text { graus? }\end{array}$ & & & & & & \\
\hline $\begin{array}{c}\text { Levantar de } \\
\text { uma cadeira? }\end{array}$ & & & & & \\
\hline
\end{tabular}

Que nota você daria para a atual função de seu joelho durante suas atividades de vida diária numa escala de 0 a 100? Considere a nota 100 a medida de seu joelho antes da lesão / trauma, e a nota 0 a total incapacidade de realizar qualquer atividade de sua rotina diária.

Nota: 
Qual das seguintes alternativas melhor descreve as funções gerais de seu joelho durante sua atividade de vida diária? (marcar apenas uma resposta)
( ) Normal
( ) Quase Normal
( ) Anormal
( ) Extremamente Anormal

Sua lesão / trauma no joelho afeta sua atividade durante as atividades de vida diária? Classifique seu atual nível de atividade: (marcar apenas uma resposta)
( ) Normal
( ) Quase Normal
( ) Anormal
( ) Extremamente Anormal 


\section{ESCALA PARA ATIVIDADES ESPORTIVAS (EAE)}

\section{Instruções:}

O seguinte questionário foi formulado para que você possa demonstrar os sintomas e limitações que apresenta no joelho quando você faz atividades esportivas. Por favor, assinale uma única resposta, ou seja, a que melhor descreve esses sintomas e limitações nos últimos dias (1 ou 2 dias). Para uma mesma pergunta, mais de uma resposta poderia servir, no entanto, assinale apenas aquela que melhor represente as dificuldades sentidas na atividade esportiva.

\section{Sintomas}

O quanto cada um desses sintomas afeta o seu nível de atividade esportiva? (Marque uma resposta em cada linha)

\begin{tabular}{|c|l|c|c|c|c|c|}
\cline { 2 - 6 } \multicolumn{1}{c|}{} & Nunca tenho & $\begin{array}{c}\text { Tenho o } \\
\text { sintoma mas } \\
\text { não afeta a } \\
\text { atividade } \\
\text { esportiva }\end{array}$ & $\begin{array}{c}\text { O sintoma } \\
\text { afeta } \\
\text { ligeiramente } \\
\text { a atividade } \\
\text { esportiva }\end{array}$ & $\begin{array}{c}\text { O sintoma afeta } \\
\text { moderadamente } \\
\text { a atividade } \\
\text { esportiva }\end{array}$ & $\begin{array}{c}\text { O sintoma } \\
\text { afeta } \\
\text { extremamente } \\
\text { a atividade } \\
\text { esportiva }\end{array}$ & $\begin{array}{c}\text { O sintoma } \\
\text { impede a } \\
\text { prática de } \\
\text { qualquer } \\
\text { atividade } \\
\text { esportiva }\end{array}$ \\
\hline $\begin{array}{c}\text { Dor } \\
\begin{array}{c}\text { Crepitação } \\
\text { (sensação de } \\
\text { areia no } \\
\text { joelho) }\end{array}\end{array}$ & & & & & & \\
\hline $\begin{array}{c}\text { Rigidez } \\
\text { Travamento }\end{array}$ & & & & & & \\
\hline $\begin{array}{c}\text { Inchaço } \\
\text { Pequena } \\
\text { instabilidade } \\
\text { (falta de } \\
\text { firmeza) }\end{array}$ & & & & & & \\
\hline $\begin{array}{c}\text { Instabilidade } \\
\text { total (falseio) }\end{array}$ & & & & & & \\
\hline Fraqueza & & & & & & \\
\hline
\end{tabular}

\section{Limitações Funcionais em Atividades Esportivas}

Como o seu joelho afeta sua capacidade de .... (marque uma resposta em cada linha)

\begin{tabular}{|c|c|c|l|l|l|l|}
\cline { 2 - 6 } \multicolumn{1}{c|}{} & $\begin{array}{c}\text { Não dificulta } \\
\text { nada }\end{array}$ & $\begin{array}{c}\text { Dificulta } \\
\text { minimamente }\end{array}$ & $\begin{array}{c}\text { Dificulta às } \\
\text { vezes }\end{array}$ & $\begin{array}{c}\text { Dificulta } \\
\text { moderadamente }\end{array}$ & $\begin{array}{c}\text { Dificulta } \\
\text { muito }\end{array}$ & $\begin{array}{c}\text { Impede de } \\
\text { realizar }\end{array}$ \\
\hline $\begin{array}{c}\text { Correr para } \\
\text { frente em } \\
\text { linha reta? }\end{array}$ & & & & & & \\
\hline $\begin{array}{c}\text { Saltar e } \\
\text { aterrissar } \\
\text { com a perna } \\
\text { envolvida? }\end{array}$ & & & & & & \\
\hline $\begin{array}{c}\text { Frear (parar) } \\
\text { e recomeçar a } \\
\text { atividade } \\
\text { rapidamente } \\
\text { (explosão) }\end{array}$ & & & & & & \\
\hline $\begin{array}{c}\text { Mudar de } \\
\text { direção e } \\
\text { girar sobre a } \\
\text { perna } \\
\text { envolvida }\end{array}$ & & & & & & \\
\hline
\end{tabular}


Que nota você daria para a atual função de seu joelho durante a atividade esportiva numa escala de 0 a 100? Considere a nota 100 a medida de seu joelho antes da lesão / trauma, e a nota 0 a total incapacidade de realizar qualquer atividade esportiva.

Nota:

Qual das seguintes alternativas melhor descreve a função geral de seu joelho na atividade esportiva? (marcar apenas uma resposta)

( ) Normal

( ) Quase Normal

( ) Anormal

( ) Extremamente Anormal

Sua lesão / trauma no joelho afeta sua atividade durante o esporte? Classifique seu atual nível de atividade: (marcar apenas uma resposta)

( ) Normal

( ) Quase Normal

( ) Anormal

( ) Extremamente Anormal

\section{Mudanças na Atividade Esportiva}

Marque seu melhor nível de atividade esportiva nos períodos de tempo representados na tabela abaixo. (uma resposta em cada linha)

\begin{tabular}{|c|c|c|c|c|}
\cline { 2 - 4 } \multicolumn{1}{c|}{} & $\begin{array}{c}\text { Prática de esportes } \\
\text { extenuantes } \\
\text { Ex.: futebol, } \\
\text { basquete, vôlei e } \\
\text { handebol }\end{array}$ & $\begin{array}{c}\text { Prática de esportes } \\
\text { moderados } \\
\text { Ex.: tênis, esqui }\end{array}$ & $\begin{array}{c}\text { Prática de esportes } \\
\text { leves } \\
\text { Ex.: bicicleta, } \\
\text { natação e golfe }\end{array}$ & $\begin{array}{c}\text { Incapacidade da } \\
\text { prática de esportes }\end{array}$ \\
\hline $\begin{array}{c}\text { Antes da lesão / } \\
\text { trauma no joelho }\end{array}$ & & & & \\
\hline $\begin{array}{c}\text { Antes do } \\
\text { tratamento para } \\
\text { lesão / trauma no } \\
\text { joelho }\end{array}$ & & & & \\
\hline Atualmente & & & & \\
\hline
\end{tabular}

Qual a frequência de suas atividades esportivas em cada um dos períodos de tempo mostrados na tabela? (uma resposta em cada linha)

\begin{tabular}{|c|c|c|c|c|}
\cline { 2 - 5 } \multicolumn{1}{c|}{} & $\begin{array}{c}\text { 4 a 7 vezes por } \\
\text { semana }\end{array}$ & $\begin{array}{c}1 \text { a 3 vezes por } \\
\text { semana }\end{array}$ & 1 a 3 vezes por mês & $\begin{array}{c}\text { Menos de 1 vez por } \\
\text { mês }\end{array}$ \\
\hline $\begin{array}{c}\text { Antes da lesão / } \\
\text { trauma no joelho }\end{array}$ & & & & \\
\hline $\begin{array}{c}\text { Antes do } \\
\text { tratamento para } \\
\text { lesão / trauma no } \\
\text { joelho }\end{array}$ & & & & \\
\hline Atualmente & & & & \\
\hline
\end{tabular}




\section{AVALIAÇÃO DA ATIVAÇÃO MUSCULAR}

TESTE NEUROMUSCULAR MANUAL

\begin{tabular}{|l|l|l|}
\hline O(a) voluntário(a) é capaz de manter a hiperextensão passiva do joelho direito? & SIM & NÃO \\
\hline O(a) voluntário(a) é capaz de manter a hiperextensão passiva do joelho esquerdo? & SIM & NÃO \\
\hline
\end{tabular}

\section{AVALIAÇÃO ISOCINÉTICA E FUNCIONAL}

ID: - Data:

Avaliador(es):

\begin{tabular}{|l|l|l|}
\hline \multicolumn{1}{|c|}{ TIPO DE AJUSTE } & DIREITO & ESQUERDO \\
\hline Deslocamento lateral do & & \\
dinamômetro & & \\
\hline Altura do braço do dinamômetro & & \\
\hline Altura do banco & & \\
\hline Deslocamento do banco & & \\
\hline Deslocamento do assento & & \\
\hline
\end{tabular}

SINGLE LEG HOP TEST

\begin{tabular}{|c|l|l|l|l|}
\cline { 2 - 5 } \multicolumn{1}{c|}{} & \#1 & $\# 2$ & & MÉDIA \\
\hline MID & & & & \\
\hline MIE & & & & \\
\hline
\end{tabular}


Y BALANCE TEST

\begin{tabular}{|c|c|c|c|}
\cline { 2 - 4 } \multicolumn{1}{c|}{} & \# A & \# M & \# L \\
\hline MID & & & \\
\hline MIE & & & \\
\hline
\end{tabular}

